\title{
CALCIUM AND PHOSPHORUS METABOLISM IN OSTEOMALACIA IX. METABOLIC BEHAVIOR OF INFANTS FED ON BREAST MILK FROM MOTHERS SHOWING VARIOUS STATES OF VITAMIN D NUTRITION
}

\author{
By S. H. LIU, H. I. CHU, C. C. SU, T. F. YU AND T. Y. CHENG \\ (From the Department of Medicine, Peiping Union Medical College, Peiping)
}

(Received for publication October 24, 1939)

It is generally recognized that the nutritional state of the mother has an important influence upon that of the infant. This influence is exerted during the antenatal period as well as during infancy when breast feeding constitutes the only or main source of nutrients. Among the numerous nutritive factors, those concerned in bone metabolism, namely, calcium, phosphorus and vitamin $D$, have recently received considerable attention. It has long been suspected that mothers with osteomalacia may give birth to children showing evidence of disturbed calcium and phosphorus metabolism in utero or in early infancy. In 1930 Maxwell and Turnbull (16) reported 2 cases of fetal rickets. The mothers of both children were suffering from advanced osteomalacia with marked pelvic deformities necessitating cesarean section. The infants showed evidence of rickets by $x$-ray, and one of them, on histological examination of the bones, exhibited deficiency in provisional calcification, irregularity of endochondral ossification from the diaphysis and slight fibrosis in the metaphysis characteristic of rickets. This is the first demonstration of the existence of fetal rickets in infants born of osteomalacic mothers. Subsequent collections of Maxwell and co-workers $(17,18,19)$ have added 15 more such cases, establishing beyond doubt the causal relationship between osteomalacia in the mother and rickets in the newborn. In fact, Maxwell (18) says that fetal rickets is certainly to be looked for where the product of serum calcium and phosphorus in the mother is below 20 , especially if the calcium factor is distinctly low.

Tetany, another manifestation of vitamin D deficiency, tends to occur early in infancy among the cases observed here. In Chu and Sung's analysis (3) of 45 cases of infantile tetany, 30 cases or 66.7 per cent appeared within the first three months of life. In view of the fact that in Europe and America spasmophilia, the identity of which with infantile tetany has been controversial, is more frequently seen after the age of six months, the much earlier age incidence of this condition in North China is probably significant. In looking for an explanation of this unusual observation, they investigated the diet, mode of living and health condition of the mothers, and found that the majority of these women subsisted on diets deficient, among other things, in calcium and vitamin $\mathrm{D}$, or had frank osteomalacia or tetany. This finding suggests to $\mathrm{Chu}$ and Sung that the high incidence of tetany in the early months of infancy may be accounted for by a congenital deficiency of vitamin D and calcium. While the importance of antenatal deficiency in the manifestation of the disease cannot be denied, neonatal nutrition as influenced by the condition of the milk of the mother probably also has a significant bearing on the problem.

In order to determine how the state of vitamin $\mathrm{D}$ nutrition of the mother during lactation affects that of the infant, opportunity has been taken to study the calcium, phosphorus and nitrogen metabolism of both the mother and the infant simultaneously in four instances. The results from the four sets of cases, though similar in demonstrating the intimate relationship between infantile and maternal metabolism during the nursing period, are sufficiently varied to be useful in illustrating the different aspects of the problem:

1. The behavior of calcium and phosphorus metabolism of an infant receiving milk from its mother who, having had osteomalacia, had been adequately treated with large doses of vitamin D and calcium during gestation.

2. The state of mineral metabolism of an infant 
TABLE I

Composition of diets in grams per day

(Values for calcium, phosphorus, and,nitrogen are actually analyzed)

\begin{tabular}{|c|c|c|c|c|c|c|c|c|c|}
\hline \multirow[b]{2}{*}{ Periods (four-day) $\ldots \ldots \ldots \ldots$} & \multicolumn{2}{|c|}{ Case 1a } & \multirow{2}{*}{ Case 2a } & \multicolumn{3}{|c|}{ Case $3 a^{\prime}$} & \multicolumn{3}{|c|}{ Case 4a } \\
\hline & $1-5$ & $6-11$ & & $\begin{array}{c}1-2 \\
10-14 \\
16-17\end{array}$ & 3-9 & $19-20$ & $1-10$ & $11-16$ & $17-26$ \\
\hline Diet number............... & 1 & 2 & $1 *$ & 1 & 2 & 3 & 3 & 4 & 5 \\
\hline 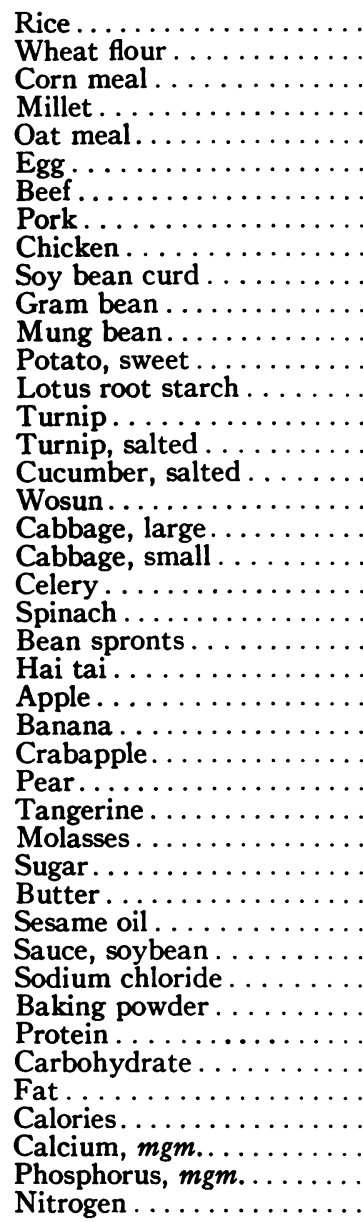 & $\begin{array}{r}10 \\
10 \\
42 \\
6 \\
60 \\
834 \\
82 \\
1994 \\
247 \\
1025 \\
11.58\end{array}$ & $\begin{array}{r}125 \\
\\
12 \\
12 \\
52 \\
7.5 \\
100 \\
293 \\
103 \\
2499 \\
309 \\
1281 \\
14.50\end{array}$ & $\begin{array}{r}20 \\
30 \\
5 \\
54 \\
749 \\
479 \\
35 \\
2528 \\
227 \\
932 \\
11.34\end{array}$ & $\begin{array}{r}100 \\
\\
20 \\
50 \\
10 \\
6 \\
20 \ddagger \\
86 \\
557 \\
62 \\
3125 \\
186 \\
930 \\
12.35\end{array}$ & $\begin{array}{r}100 \\
\\
20 \\
100 \\
50 \\
\\
40 \\
20 \\
50 \\
10 \\
9 \\
20 \ddagger \\
88 \\
509 \\
65 \\
2972 \\
505 \\
1157 \\
13.76\end{array}$ & $\begin{array}{r}20 \\
60 \\
10 \\
8 \\
\\
102 \\
411 \\
88 \\
2844 \\
421 \\
1174 \\
16.25\end{array}$ & $\begin{array}{r}50 \\
10 \\
70 \\
374 \\
73 \\
2435 \\
207 \\
812 \\
10.61\end{array}$ & $\begin{array}{r}50 \\
10 \\
88 \\
889 \\
75 \\
2980 \\
292 \\
1065 \\
12.96\end{array}$ & $\begin{array}{r}50 \\
12 \\
\\
100 \\
561 \\
76 \\
3329 \\
456 \\
1006 \\
14.84\end{array}$ \\
\hline
\end{tabular}

* Half portion of this diet was used for periods 2-4, and two-thirds portion for periods 5-6 and 10-12 inclusive.

† Only 400 grams of flour were used for periods $10-14$; and 300 grams for periods 16-17, inclusive. Flour on analysis gave $21 \mathrm{mgm}$. calcium, $133 \mathrm{mgm}$. phosphorus, and 1.63 grams nitrogen per 100 grams.

† Baking powder on analysis contained $986 \mathrm{mgm}$. calcium, and $1,587 \mathrm{mgm}$. phosphorus in 20 grams. This was used during periods 7-9 (diet 2) and 10-11 (diet 1) only, accounting for the exceedingly high intake of calcium and phosphorus during those periods.

with tetany and rickets, breast-fed by its mother who also had tetany as well as osteomalacia; and the changes brought about both in the infant and in the mother after the latter alone received vita$\min \mathrm{D}$.

3. The response of an infant, born of an osteomalacic mother and itself having tetany and rickets, to breast feeding from a presumably normal wet nurse before and after vitamin $D$ administration to the wet nurse.

4. The effect on an infant of variations in the state of vitamin D nutrition in the mother who had osteomalacia: a limited dose of vitamin D during the latter part of pregnancy, depletion for a period after parturition, and finally replenishment. 


\section{PROCEDURE}

All the patients were studied in the metabolism ward where the routines for the preparation and serving of constant diets and collection of excreta for quantitative purposes have been standardized $(7,13,14)$. The composition of the diets is shown in Table $I$. While the fuel values are calculated from the compilation of $\mathrm{Wu}$ (25) and from Outline of Diets of the Peiping Union Medical College Hospital, 3rd edition, Peiping, 1937, the calcium, phosphorus and nitrogen contents were analyzed, 50 per cent of the day's food being used for the purpose. Where the same diet was used for a relatively long period of time, the analyses were repeated at intervals.

Stools and urine were collected in four-day periods, 0.1 gram of carmine being used to mark off the stools every four days. For the quantitative collection of excreta from infants, the special metabolism cots, described by Tso (23), were used. As all the infants studied were male, the urine collection was satisfactory and complete. It is usually a good plan, if time permits, to interpose periods of rest between periods of study so as to avoid maceration of the skin of the perineum and possible ill effects of continuous restriction of activities of the infant.

Stools were passed directly into tared enamel pans, dried in an oven at 90 to $100^{\circ} \mathrm{C}$., and weighed. All the stools of the period were ground in a mill into a fine homogeneous powder, and accurately weighed portions ashed in a muffle furnace at approximately $500^{\circ} \mathrm{C}$. The ash was extracted with hot 5 per cent hydrochloric acid and portions taken for analysis of calcium and phosphorus. The four-day pooled collection of urine was preserved by the addition of $5 \mathrm{cc}$. of concentrated hydrochloric acid per liter and analyzed for the same elements.

Breasts were emptied five or six times every twentyfour hours by means of a hand or electric breast pump. A measured amount of each milking was fed to the infant from a feeding bottle, and a small aliquot was saved. The pooled specimens of one or four days were used for analysis. Venipunctures were done before breakfast at the beginning of each period, but less frequently in the case of infants.

The analytical procedures for calcium and phosphorus in stool, urine, blood, milk and food have been given previously $(7,13,14)$. The macro-Kjeldahl method was used for nitrogen determinations.

\section{RESULTS}

Composition of milk. All the lactating women included in this study were good milk-providers.

TABLE II

Composition of breast milk

\begin{tabular}{|c|c|c|c|c|c|c|c|c|c|c|c|c|c|c|c|c|}
\hline \multirow{2}{*}{$\begin{array}{c}\text { Four- } \\
\text { day } \\
\text { period }\end{array}$} & \multicolumn{4}{|c|}{ Case 1a } & \multicolumn{4}{|c|}{ Case 2a } & \multicolumn{4}{|c|}{ Case 3a' } & \multicolumn{4}{|c|}{ Case 4a } \\
\hline & $\begin{array}{l}\text { Vol- } \\
\text { ume }\end{array}$ & $\begin{array}{l}\text { Cal- } \\
\text { cium }\end{array}$ & $\begin{array}{l}\text { Phos- } \\
\text { phorus }\end{array}$ & $\underset{\text { trogen }}{N_{1-}-}$ & $\begin{array}{l}\text { Vol- } \\
\text { ume }\end{array}$ & $\begin{array}{l}\text { Cal- } \\
\text { cium }\end{array}$ & $\begin{array}{l}\text { Phos- } \\
\text { phorus }\end{array}$ & $\underset{\text { trogen }}{\mathrm{Ni}-}$ & $\begin{array}{l}\text { Vol- } \\
\text { ume }\end{array}$ & $\begin{array}{l}\text { Cal- } \\
\text { cium }\end{array}$ & $\begin{array}{l}\text { Phos- } \\
\text { phorus }\end{array}$ & $\underset{\text { trogen }}{\mathrm{N}_{1}-}$ & $\begin{array}{l}\text { Vol- } \\
\text { ume }\end{array}$ & $\begin{array}{l}\text { Cal- } \\
\text { cium }\end{array}$ & $\begin{array}{l}\text { Phos- } \\
\text { phorus }\end{array}$ & $\underset{\text { trogen }}{\mathrm{N}_{1-}-}$ \\
\hline & $c c$. & $\underset{\substack{\text { pger } \\
\text { cent }}}{\text { cen }}$ & $\underset{\substack{\text { per } \\
\text { cent }}}{\operatorname{mgm} .}$ & $\begin{array}{c}\text { mgm. } \\
\text { per } \\
\text { cent }\end{array}$ & $c c$. & 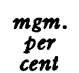 & $\underset{\substack{\text { per } \\
\text { cent }}}{\text { mgm. }}$ & $\underset{\substack{\text { per } \\
\text { cent }}}{\text { mgm. }}$ & c. & $\begin{array}{c}\text { mgm. } \\
\text { per } \\
\text { cent }\end{array}$ & $\begin{array}{c}\text { mgm. } \\
\text { per } \\
\text { cent }\end{array}$ & $\begin{array}{c}\text { per } \\
\text { cent }\end{array}$ & $c c$. & $\begin{array}{c}\text { mgm. } \\
\text { per } \\
\text { cent }\end{array}$ & $\begin{array}{c}\text { mgm. } \\
\text { per } \\
\text { cent }\end{array}$ & $\begin{array}{c}\text { mgm. } \\
\text { per } \\
\text { cent }\end{array}$ \\
\hline & 819 & 30.95 & 22.92 & 277.9 & 922 & 35.30 & 16.21 & 180.5 & 558 & 32.28 & 13.69 & 217.4 & 498 & 25.74 & 16.51 & 241.0 \\
\hline 2 & 936 & 30.67 & 22.83 & 274.8 & 952 & 31.48 & 15.00 & 154.7 & 623 & 34.20 & 14.32 & 215.0 & 581 & 27.90 & 16.85 & 232.6 \\
\hline 3 & 1041 & 29.68 & 20.62 & 259.9 & 904 & 33.20 & 14.88 & 167.0 & 654 & 34.18 & 14.25 & 221.7 & 680 & 27.80 & 17.85 & 235.7 \\
\hline 4 & 1116 & 30.56 & 19.52 & 249.5 & 877 & 34.20 & 15.36 & 203.0 & 739 & 30.76 & 15.62 & 221.4 & 780 & 26.80 & 17.02 & 226.7 \\
\hline 5 & 1146 & 30.62 & 18.64 & 225.4 & 907 & 32.34 & 15.68 & 167.0 & 798 & 30.96 & 13.95 & 206.6 & 867 & 30.16 & 16.44 & 215.2 \\
\hline 6 & 1230 & 31.30 & 17.45 & 226.0 & 908 & 31.80 & 16.83 & 177.5 & 837 & 33.39 & 13.28 & 213.8 & 928 & 30.40 & 17.12 & 212.3 \\
\hline 7 & 1236 & 32.06 & 17.76 & 222.8 & 906 & 29.00 & 15.84 & 165.2 & 870 & 30.78 & 12.38 & 203.0 & 981 & 29.30 & 16.00 & 205.3 \\
\hline 8 & 1274 & 31.35 & 17.16 & 222.7 & 902 & 31.98 & 14.98 & 188.6 & 794 & 28.04 & 12.48 & 199.7 & 1009 & 27.80 & 16.00 & 198.0 \\
\hline 9 & 1309 & 31.70 & 16.25 & 214.0 & 906 & 32.07 & 16.20 & 197.5 & 800 & 28.63 & 11.68 & 199.0 & 1070 & 29.50 & 14.36 & 192.0 \\
\hline 10 & 1353 & 31.46 & 16.38 & 210.3 & 976 & 32.52 & 15.70 & 189.8 & 927 & 33.68 & 15.18 & 194.0 & 1079 & 29.25 & 14.52 & 185.2 \\
\hline 11 & 1367 & 30.32 & 16.00 & 210.2 & 1030 & 31.94 & 14.90 & 190.0 & 1016 & 30.83 & 13.06 & 194.0 & 1145 & 27.89 & 14.02 & 170.8 \\
\hline 12 & & & & & 1118 & 32.20 & 15.51 & 165.3 & 1007 & 33.59 & 12.08 & 196.9 & 1184 & 27.30 & 13.96 & 172.2 \\
\hline $\begin{array}{l}13 \\
14\end{array}$ & & & & & & & & & 980 & 29.85 & 11.88 & 181.5 & $\begin{array}{l}1175 \\
1183\end{array}$ & $\begin{array}{l}29.60 \\
20.40\end{array}$ & 14.68 & $\begin{array}{l}176.4 \\
1685\end{array}$ \\
\hline $\begin{array}{l}14 \\
15\end{array}$ & & & & & & & & & 966 & 30.34 & 11.63 & 183.3 & 1200 & 28.96 & 14.70 & 165.6 \\
\hline 16 & & & & & & & & & non & 28.60 & 11.50 & 1.843 & 1229 & 27.63 & 13.08 & 161.4 \\
\hline 17 & & & & & & & & & & & 12.60 & 1.760 & 1256 & 27.19 & 13.15 & 156.8 \\
\hline 18 & & & & & & & & & & & 1240 & & 1248 & & 128 & a \\
\hline 19 & & & & & & & & & 1087 & 27.90 & $\begin{array}{l}13.42 \\
12.28\end{array}$ & & 1248 & $\begin{array}{r}26.09 \\
5.62\end{array}$ & 12.14 & 157.8 \\
\hline $\begin{array}{l}20 \\
21\end{array}$ & & & & & & & & & $\begin{array}{l}1132 \\
1066\end{array}$ & $\begin{array}{l}21.09 \\
27.00\end{array}$ & $\begin{array}{l}12.28 \\
11.44\end{array}$ & 152.0 & $\begin{array}{l}1240 \\
1268\end{array}$ & $\begin{array}{l}23.03 \\
24.41\end{array}$ & $\begin{array}{l}12.20 \\
12.34\end{array}$ & $\begin{array}{l}100.0 \\
164.8\end{array}$ \\
\hline 22 & & & & & & & & & 1008 & 27.69 & 11.48 & 159.0 & 1156 & 26.06 & 12.31 & 161.6 \\
\hline 23 & & & & & & & & & & & & & 1236 & 26.59 & 12.91 & 169.9 \\
\hline 24 & & & & & & & & & & & & & & 25.29 & 12.56 & 159. \\
\hline 25 & & & & & & & & & & & & & & & 11.9 & 157 \\
\hline & & & & & & & & & & & & & & & 12.46 & 145 \\
\hline
\end{tabular}

Note: Studies of milk started eighteen days postpartum in Case 1a, two months in Case 2a, one month in Case 3a', and seventeen days in Case $4 a$. Values are expressed as daily averages for each four-day period. 
They were all in early stages of lactation. The milk yield, starting from 500 to $900 \mathrm{cc}$. per day, gradually increased so that eventually it exceeded 1 liter in Cases $2 \mathrm{a}$ and $3 \mathrm{a}^{\prime}$ and 1.3 liters in Cases 1a and 4a (Table II). The average calcium content varied from 27 to $32 \mathrm{mgm}$. per $100 \mathrm{cc}$. in the 4 cases. Slight fluctuations in calcium content from period to period were noticeable, but these could not be definitely correlated with progression of time, with the institution of vitamin $D$, or with the different levels of calcium intake. However, a descending tendency with the lapse of time was discernible in both the phosphorus and nitrogen content, particularly in Cases $3 \mathrm{a}^{\prime}$ and $4 \mathrm{a}$, in which the studies extended over eighty-eight and one hundred and four days respectively. The average phosphorus content was from 13 to 18 mgm. per $100 \mathrm{cc}$. and the average protein was from 1.7 to 2.2 per cent. The figures for calcium and phosphorus were within the limits of normal variation in the composition of human milk as compiled by Leitch (11).

Case 1a. Mother Y.W. L. While anatomical evidence of osteomalacia was still present during this study, the disease was considered to be at the healing stage due to the large intake of calcium, phosphorus and vitamin D given during the last seven months of pregnancy. Studies began eighteen days postpartum. As seen from Figure 1 and Table III, calcium intake had to be raised to over 2 grams before a slight positive balance could be obtained. As discussed in a previous communication (12), this rather "extravagant" behavior was not the result of vitamin D deficiency, as Vigantol given during periods 7 to 11 made no difference to the calcium balance. It was considered very likely that the physiological requirements during active lactation rendered conservation very difficult and that the large amounts of calcium gained during pregnancy made further storage less urgent than in cases with less adequate preparation during pregnancy. Phosphorus metabolism was parallel to calcium metabolism. Serum calcium and inorganic phosphorus remained within low normal levels throughout the period of observations.

Case 1b. Infant $Y . W . L$. This infant was normal in every way. He was fed solely on the mother's milk. Metabolic observations were made for 7 four-day periods (periods 3 to 9 ). The intake of calcium increased progressively from 280 to $363 \mathrm{mgm}$. per day as milk consumption increased (Figure 1 and Table IV). The urinary and fecal excretion of calcium was equal in extent, and both were minimal so that marked positive calcium balances were obtained, the average daily retention amounting to 74 per cent of the intake with very little variation from period to period. The same may
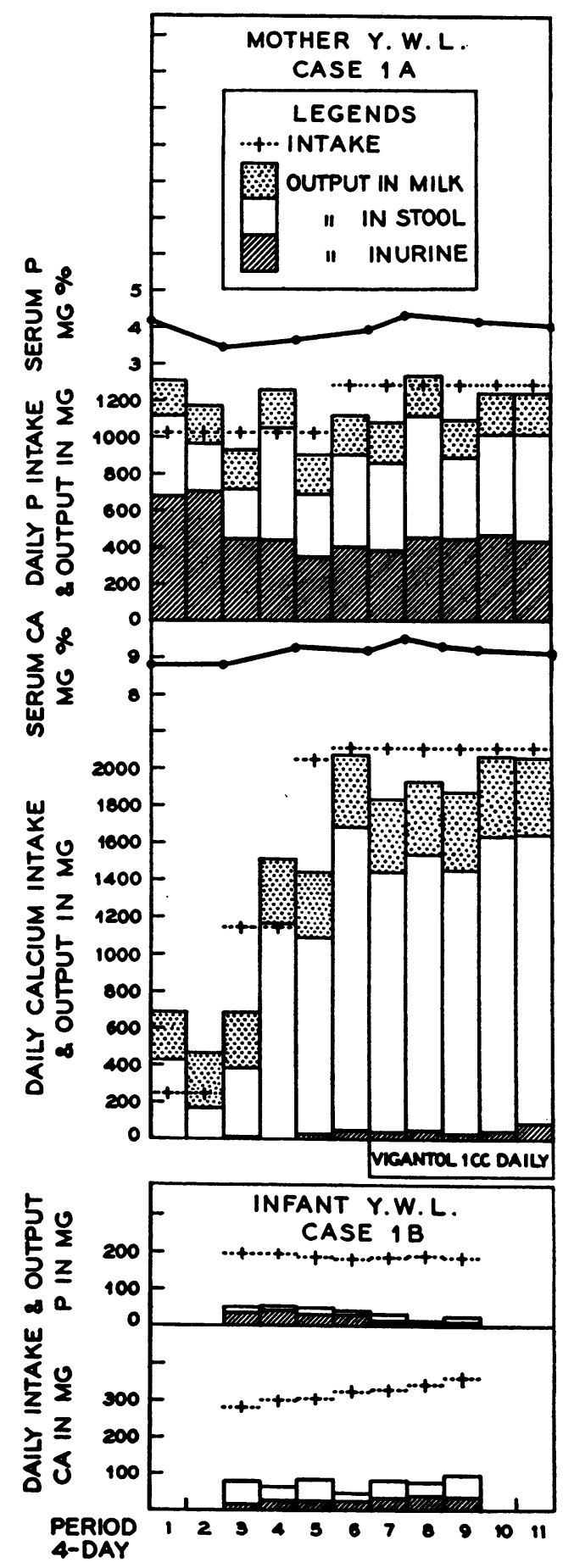

Fig. 1. Calcium and Phosphorus Metabolism of CAses 1A AND 1B

The lactating mother had healing osteomalacia with adequate prior store and subsequent administration of vitamin D. The infant exhibited remarkably good retention of calcium and phosphorus throughout the periods of observation. 
TABLE III

Mother Y.W.L. Case 1a. Calcium, phosphorus and nitrogen metabolism in a case of healing osteomalacia during lactation with adequate vitamin $D$ supply

\begin{tabular}{|c|c|c|c|c|c|c|c|c|c|c|c|c|c|c|c|c|c|c|}
\hline \multirow{2}{*}{$\begin{array}{l}\text { Date } \\
1935\end{array}$} & \multirow{2}{*}{$\begin{array}{l}\text { Period } \\
\text { four- } \\
\text { day }\end{array}$} & \multicolumn{5}{|c|}{ Calcium, average per day } & \multicolumn{5}{|c|}{ Phosphorus, average per day } & \multicolumn{5}{|c|}{ Nitrogen, average per day } & \multicolumn{2}{|c|}{ Serum } \\
\hline & & $\underset{\text { take }}{\text { In- }}$ & Urine & Stool & Milk & $\begin{array}{l}\text { Bal- } \\
\text { ance }\end{array}$ & $\begin{array}{c}\text { In- } \\
\text { take }\end{array}$ & Urine & Stool & Milk & $\begin{array}{l}\text { Bal- } \\
\text { ance }\end{array}$ & $\begin{array}{l}\text { In- } \\
\text { take }\end{array}$ & Urine & Stool & Milk & $\begin{array}{l}\text { Bal- } \\
\text { ance }\end{array}$ & $\begin{array}{c}\text { Cal- } \\
\text { cium }\end{array}$ & $\begin{array}{l}\text { Phos- } \\
\text { phorus }\end{array}$ \\
\hline & & $m g m$. & mgm. & $m g m$. & mgm. & mgm. & $\boldsymbol{m g} \boldsymbol{m}$. & mgm. & & mgm. & mgm. & mgm. & $m g m$. & mgm. & $m g m$. & $m \boldsymbol{g m}$. & $\begin{array}{c}\text { mgm. } \\
\text { per } \\
\text { cent }\end{array}$ & $\begin{array}{c}\text { mgm. } \\
\text { per } \\
\text { cent }\end{array}$ \\
\hline $\begin{array}{cc}\text { IV30-V3 } \\
\text { V } & 4-7 \\
\text { V } & 8-11 \\
\text { V12-15 } \\
\text { V16-19 } \\
\text { V20-23 } \\
\text { V24-27 } \\
\text { V28-31 } \\
\text { VI } & 1-4 \\
\text { VI } & 5-8 \\
\text { VI } & 9-12\end{array}$ & $\begin{array}{c}1 \\
2 \\
3 \\
4 \\
5 \\
6 \\
7 * \\
8 \\
9 \\
10 \\
11\end{array}$ & $\begin{array}{r}247 \\
247 \\
1147 \\
1147 \\
2047 \\
2109 \\
2109 \\
2109 \\
2109 \\
2109 \\
2109\end{array}$ & $\begin{array}{r}1 \\
1 \\
11 \\
0 \\
25 \\
46 \\
40 \\
51 \\
30 \\
44 \\
85\end{array}$ & $\begin{array}{r}427 \\
178 \\
370 \\
1162 \\
1062 \\
1635 \\
1398 \\
1483 \\
1422 \\
1591 \\
1544\end{array}$ & $\begin{array}{l}253 \\
287 \\
308 \\
339 \\
351 \\
385 \\
396 \\
399 \\
416 \\
426 \\
417\end{array}$ & $\begin{array}{l}-434 \\
-219 \\
+458 \\
-354 \\
+609 \\
+43 \\
+275 \\
+176 \\
+241 \\
+48 \\
+66\end{array}$ & $\begin{array}{l}1025 \\
1025 \\
1025 \\
1025 \\
1025 \\
1281 \\
1281 \\
1281 \\
1281 \\
1281 \\
1281\end{array}$ & \begin{tabular}{|l}
681 \\
702 \\
422 \\
439 \\
348 \\
398 \\
382 \\
450 \\
444 \\
461 \\
434 \\
\end{tabular} & $\begin{array}{l}440 \\
265 \\
274 \\
602 \\
341 \\
505 \\
473 \\
663 \\
435 \\
548 \\
576\end{array}$ & \begin{tabular}{|l|}
188 \\
213 \\
214 \\
217 \\
214 \\
215 \\
219 \\
218 \\
212 \\
222 \\
219
\end{tabular} & $\begin{array}{l}-284 \\
-155 \\
+115 \\
-233 \\
+122 \\
+163 \\
+207 \\
-50 \\
+190 \\
+50 \\
+52\end{array}$ & $\begin{array}{l}11.58 \\
11.58 \\
11.58 \\
11.58 \\
11.58 \\
14.50 \\
14.50 \\
14.50 \\
14.50 \\
14.50 \\
14.50\end{array}$ & $\begin{array}{l}7.01 \\
7.06 \\
7.33 \\
7.65 \\
6.64 \\
7.89 \\
8.82 \\
9.72 \\
9.43 \\
9.26 \\
9.40\end{array}$ & $\begin{array}{l}1.26 \\
0.93 \\
0.64 \\
1.14 \\
1.08 \\
1.60 \\
1.43 \\
1.72 \\
1.45 \\
1.71 \\
1.78\end{array}$ & $\begin{array}{l}2.28 \\
2.57 \\
2.70 \\
2.78 \\
2.59 \\
2.78 \\
2.78 \\
2.84 \\
2.80 \\
2.87 \\
2.90\end{array}$ & $\begin{array}{l}+1.03 \\
+1.02 \\
+0.91 \\
+0.01 \\
+1.27 \\
+2.23 \\
+1.47 \\
+0.22 \\
+0.82 \\
+0.66 \\
+0.42\end{array}$ & $\begin{array}{l}8.76 \\
8.80 \\
9.23 \\
9.20 \\
9.32 \\
9.07\end{array}$ & $\begin{array}{l}4.23 \\
3.40 \\
3.60 \\
3.88\end{array}$ \\
\hline
\end{tabular}

This table is reproduced from Chinese J. Physiol., 1937, 11, 292 (12), for convenience.

- Vigantol $0.6 \mathrm{cc}$. daily was started from this period.

also be said of the phosphorus metabolism, the average daily retention being 80 per cent. Nitrogen balance was likewise positive, approximately $\mathbf{5 0}$ per cent of the intake being retained. Both the calcium and phosphorus balances were much more than normal, as discissed later.

The results on this infant show the remarkable manner in which the mineral elements of human milk were utilized with very little wastage. It is very likely that the vitamin D present in the milk, together with the store of the vitamin acquired during the antenatal period, was responsible for the extreme degree of conservation in calcium and phosphorus exchange exhibited by the infant. Extra ingestion of Vigantol by the mother did not further improve the degree of mineral conservation.

Case 2a. Mother C. S. Y. This patient had tentany and mild osteoporosis of the visualized long bones at the time of metabolic observation. As shown in Figure 2 and Table V, while on a minimal calcium intake of 227 mgm. per day, the patient exhibited a moderately negative balance (period 1). With the intake raised to over 900 mgm., the loss of calcium was rectified (periods 2 and 3 ), but no substantial retention of the element took place until vitamin $D$ was given (periods 4 to 12). The first 2 periods of Vigantol administration ( 1 cc. per day, equivalent to 12,000 international units) were without effect, but from the third period on, retention amounted to from 30 to 40 per cent of the intake. This retention was brought about entirely by a reduction in the fecal calcium output, the secretion of calcium in the milk being maintained. At the height of vitamin $\mathrm{D}$ action (periods 10 to 12) small amounts of calcium appeared in the urine, indicating that intestinal absorption had improved to such an extent as to be more than sufficient for the needs of the body.

Phosphorus balance was markedly negative in the beginning but with vitamin $\mathrm{D}$ administration considerable

TABLE IV

Infant Y.W.L. Case 1b. Calcium, phosphorus and nitrogen metabolism of a presumably normal infant fed exclusively on mother's milk

\begin{tabular}{|c|c|c|c|c|c|c|c|c|c|c|c|c|c|c|c|c|c|c|}
\hline \multirow{2}{*}{$\begin{array}{l}\text { Date } \\
1935\end{array}$} & \multirow{2}{*}{$\begin{array}{l}\text { Period } \\
\text { four- } \\
\text { day }\end{array}$} & \multirow{2}{*}{$\begin{array}{c}\text { Breast } \\
\text { milk } \\
\text { intake }\end{array}$} & \multicolumn{5}{|c|}{ Calcium, average per day } & \multicolumn{5}{|c|}{ Phosphorus, aserage per day } & \multicolumn{5}{|c|}{ Nitrogen, average per day } & \multirow{2}{*}{$\begin{array}{l}\text { Body } \\
\text { weight }\end{array}$} \\
\hline & & & $\underset{\text { In- }}{\text { Inke }}$ & Urine & Stool & $\begin{array}{l}\text { Bal- } \\
\text { ance }\end{array}$ & $\begin{array}{c}\text { Reten- } \\
\text { tion }\end{array}$ & $\begin{array}{c}\text { In- } \\
\text { take }\end{array}$ & Urine & Stool & $\begin{array}{l}\text { Bal- } \\
\text { ance }\end{array}$ & $\begin{array}{c}\text { Reten- } \\
\text { tion }\end{array}$ & $\begin{array}{c}\text { In- } \\
\text { take }\end{array}$ & Urine & Stool & $\begin{array}{l}\text { Bal- } \\
\text { ance }\end{array}$ & $\begin{array}{c}\text { Reten- } \\
\text { tion }\end{array}$ & \\
\hline $\begin{array}{l}\text { V } 8-11 \\
\text { V12-15 } \\
\text { V16-19 } \\
\text { V20-23 } \\
\text { V24-27 } \\
\text { V28-31 } \\
\text { VI } 1-4\end{array}$ & $\begin{array}{l}3 \\
4 \\
5 \\
6 \\
7 * \\
8 \\
9\end{array}$ & $\begin{array}{c}c c . \\
944 \\
985 \\
995 \\
1034 \\
1027 \\
1102 \\
1142\end{array}$ & $\begin{array}{l}m g m . \\
280 \\
301 \\
305 \\
324 \\
329 \\
346 \\
363\end{array}$ & $\begin{array}{c}m g m . \\
18 \\
28 \\
26 \\
26 \\
36 \\
41 \\
36\end{array}$ & $\begin{array}{c}m g m \\
60 \\
36 \\
60 \\
20 \\
47 \\
36 \\
62\end{array}$ & $\begin{array}{r}m g m . \\
+202 \\
+237 \\
+219 \\
+278 \\
+246 \\
+269 \\
+265\end{array}$ & $\begin{array}{l}\text { per } \\
\text { cent } \\
72 \\
79 \\
72 \\
86 \\
75 \\
78 \\
73\end{array}$ & $\begin{array}{l}m g m . \\
195 \\
192 \\
185 \\
180 \\
182 \\
189 \\
185\end{array}$ & \begin{tabular}{|c|}
$m g m$. \\
35 \\
42 \\
30 \\
23 \\
15 \\
6 \\
10
\end{tabular} & $\begin{array}{r}m g m . \\
15 \\
11 \\
18 \\
7 \\
17 \\
9 \\
17\end{array}$ & $\begin{array}{r}m g m . \\
+145 \\
+139 \\
+137 \\
+150 \\
+150 \\
+174 \\
+158\end{array}$ & $\begin{array}{l}\text { per } \\
\text { cent } \\
74 \\
72 \\
74 \\
83 \\
82 \\
92 \\
85\end{array}$ & $\begin{array}{l}m g m . \\
2.45 \\
2.46 \\
2.24 \\
2.34 \\
2.28 \\
2.44 \\
2.45\end{array}$ & $\begin{array}{l}\text { mgm. } \\
1.03 \\
1.18 \\
0.93 \\
1.25 \\
1.02 \\
1.09 \\
1.12\end{array}$ & $\begin{array}{l}m g m . \\
0.24 \\
0.12 \\
0.27 \\
0.10 \\
0.19 \\
0.11 \\
0.11\end{array}$ & $\begin{array}{r}m g m . \\
+1.25 \\
+1.16 \\
+1.04 \\
+0.99 \\
+1.07 \\
+1.24 \\
+1.22\end{array}$ & $\begin{array}{l}\text { per } \\
\text { cent } \\
51 \\
47 \\
46 \\
42 \\
47 \\
51 \\
50\end{array}$ & $\begin{array}{l}\text { kgm. } \\
3.82 \\
3.97 \\
4.13 \\
4.30 \\
4.45 \\
4.73 \\
4.97\end{array}$ \\
\hline
\end{tabular}

* Mother started to receive renewed vitamin D supply. 

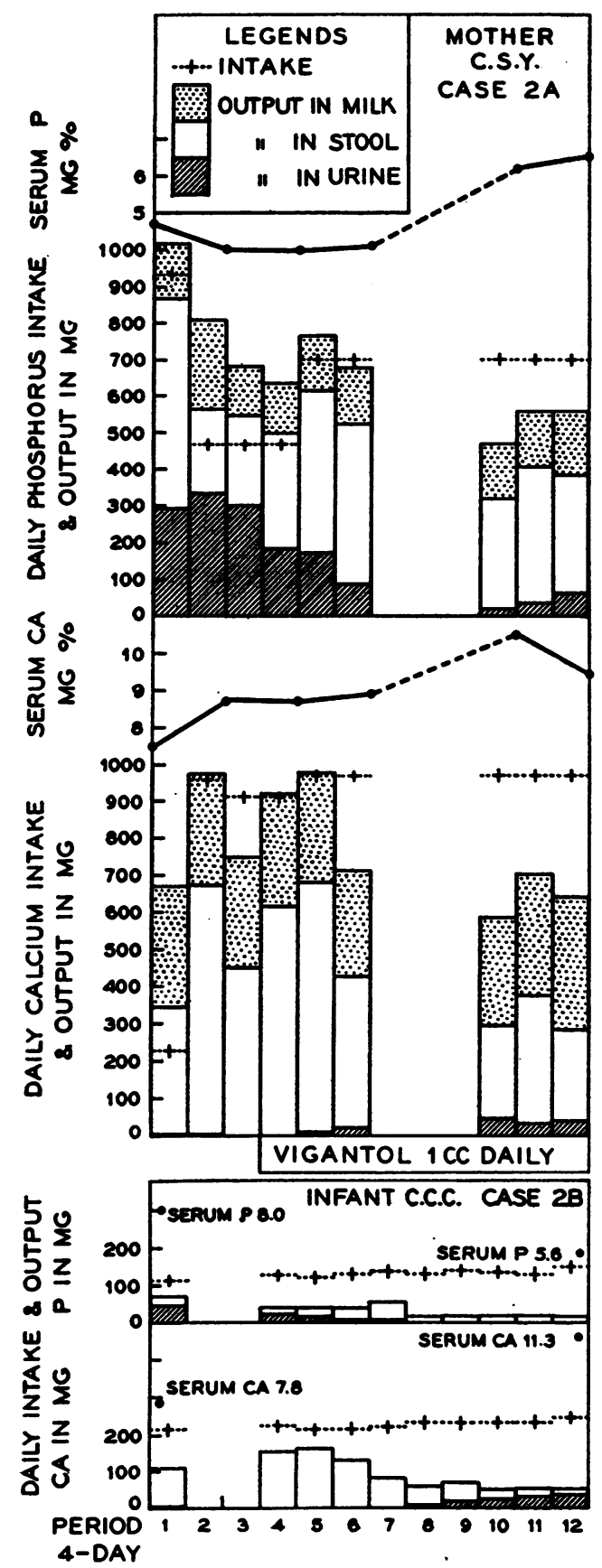

Fig. 2. Calcium and Phosphorus Metabolism of Cases 2A ANd 2B

The lactating osteomalacia mother showed poor calcium and phosphorus balances which were subsequently improved by Vigantol therapy. A similar state of affairs was reflected in the infant (with rickets and tetany) via breast milk. amounts of phosphorus were stored. The conservation of phosphorus, in contrast to that of calcium, was brought about mainly by a diminution in the urinary phosphorus output. Serum calcium, rather low to start with, was raised to normal after vitamin $\mathrm{D}$ therapy; and inorganic phosphorus was increased from a normal level on admission to a level higher than normal toward the end of the experiment.

This patient, then, differs from the first patient in that vitamin $\mathrm{D}$ therapy was capable of conserving the calcium and phosphorus metabolism so that not only were the extensive requirements of active lactation covered, but also considerable amounts of these minerals were retained in her own tissues and skeleton, which were probably in urgent need of reparation.

Case $2 b$. Infant $C$. C. C. The metabolism of the infant (Figure 2 and Table VI) reflects that of the mother. He was likewise admitted for tetany with evidence of rickets. The calcium retention of 48 per cent (period 1), as compared with that of the first infant, was poor, and it remained so during periods 4 to 6 when the mother began to receive vitamin $D$. But from period 7 on, the fecal output of calcium showed progressive reduction so that retention attained 80 per cent, comparable to the best performance of the first infant. The reduction of fecal calcium was accompanied by the appearance and increase of calcium in the urine.

Phosphorus balance was small in the beginning but it was very much increased after vitamin $D$ therapy. The average retention of phosphorus during the last 5 periods was 88 per cent of the intake. Nitrogen retention, however, remained around 50 per cent. Serum calcium increased from $7.8 \mathrm{mgm}$. at the beginning to $11.32 \mathrm{mgm}$. at the end of the experiment, while inorganic phosphorus decreased from $8.0 \mathrm{mgm}$. to $5.61 \mathrm{mgm}$. The rachitic bone changes present on admission, however, were not altered on discharge, the period during which the infant was fed the breast milk of the mother receiving vitamin $\mathrm{D}$ being only thirty-six days.

Although on roentgenologic examination there was no obvious evidence of healing in the rickets of the infant within thirty-six days, the metabolic defects characteristic of rickets and tetany were corrected. This shows that the amount of vitamin D given to the mother was sufficient to enrich her milk and to render it effective in correcting the faulty mineral metabolism of the infant. Were the period of observation extended, healing of the rachitic bone changes would have followed eventually.

Case $3 a^{\prime}$. Wet nurse $W . C . S$. This was presumably a normal lactating woman. Her metabolic behavior (Figure 3 and Table VII) may be taken to represent a normal state of affairs during lactation and it is closely comparable to that of Case 1a with healed osteomalacia. Marked negative balances in calcium were obtained on intakes of from 186 to $505 \mathrm{mgm}$. per day (periods 1 to 6 ). It was only after the calcium intake was raised to about 1,500 to $2,000 \mathrm{mgm}$. that slightly positive balances began to appear (periods 7 to 11 ). Vitamin $D$ in the form of Vigantol $1 \mathrm{cc}$. or 12,000 international units per 
TABLE V

Mother C.S. Y. Case 2a. Calcium, phosphorus and nitrogen metabolism in a case of tetany and osteomalacia during lactation before and after vitamin $D$ therapy

\begin{tabular}{|c|c|c|c|c|c|c|c|c|c|c|c|c|c|c|c|c|c|c|}
\hline \multirow{2}{*}{$\begin{array}{l}\text { Date } \\
1937\end{array}$} & \multirow{2}{*}{$\begin{array}{l}\text { Period } \\
\text { four- } \\
\text { day }\end{array}$} & \multicolumn{5}{|c|}{ Calcium, average per day } & \multicolumn{5}{|c|}{ Phosphorus, average per day } & \multicolumn{5}{|c|}{ Nitrogen, average per day } & \multicolumn{2}{|c|}{ Serum } \\
\hline & & $\begin{array}{c}\text { In- } \\
\text { take }\end{array}$ & Urine & Stool & Milk & $\begin{array}{l}\text { Bal- } \\
\text { ance }\end{array}$ & $\begin{array}{l}\text { In- } \\
\text { take }\end{array}$ & Urine & Stool & Milk & $\underset{\text { ance }}{\text { Bal- }}$ & $\begin{array}{c}\text { In- } \\
\text { take }\end{array}$ & Urine & Stool & Milk & $\begin{array}{l}\text { Bal- } \\
\text { ance }\end{array}$ & $\underset{\text { cium }}{\text { Cal- }}$ & $\begin{array}{l}\text { Phos- } \\
\text { phorus }\end{array}$ \\
\hline & & mgm. & mgm. & mgm. & mgm. & $m g m$. & mgm. & mgm. & mgm. & mgm. & mgm. & $m g m$. & mgm. & mgm. & $\mathbf{m g m}$ & mgm. & $\underset{\substack{\text { per } \\
\text { cent }}}{\text { mgm. }}$ & $\underset{\substack{\text { per } \\
\text { cent }}}{\operatorname{mgm} .}$ \\
\hline IV 6-9 & 1 & 227 & 6 & 340 & 326 & -445 & 932 & 296 & 571 & 150 & -85 & 11.34 & 5.92 & 2.31 & 1.67 & +1 & 7.46 & 4.70 \\
\hline IV10 & 2 & 958 & 5 & 671 & 300 & -18 & $46 \overline{6}$ & 336 & 331 & 143 & -344 & 5.67 & 5.99 & 1.42 & 1.47 & -3.21 & & \\
\hline IV & 3 & 914 & 4 & 446 & 300 & +164 & 466 & 302 & 245 & 134 & -215 & 5.67 & 4.24 & 0.57 & 1.51 & -0.65 & 8.72 & 4.05 \\
\hline & $4^{*}$ & 914 & 4 & 613 & 300 & -3 & 466 & 183 & 317 & 135 & -169 & 5.67 & 4.66 & 0.57 & 1.89 & -1 & & \\
\hline IV & 5 & 970 & 9 & 674 & 293 & -6 & 699 & 172 & 442 & 142 & -57 & 8.52 & 5.44 & 0.96 & 1.51 & +0.61 & 8.70 & 4.03 \\
\hline IV & 6 & 970 & 21 & 407 & 288 & +254 & 699 & 80 & 436 & 153 & +21 & 8.52 & 5.27 & 1.85 & 1.61 & -0.21 & & \\
\hline V12-15 & 10 & 970 & 46 & 223 & 318 & +383 & 699 & 20 & 299 & 153 & +227 & 8.52 & 5.09 & 0.97 & 1.85 & & & \\
\hline & 11 & 970 & 34 & 342 & 329 & +265 & .699 & 37 & 370 & 154 & +138 & 8.52 & 5.22 & 1.44 & 1.96 & -0.10 & 10.45 & 6.24 \\
\hline & 12 & 970 & 38 & 244 & 360 & +328 & 699 & 62 & 324 & 174 & +139 & 8.52 & 4.70 & 1.50 & 1.85 & +0.47 & 9.42 & 6.52 \\
\hline
\end{tabular}

* Vigantol 1 cc. started from this period.

TABLE VI

Infant C. C. C. Case 2b. Calcium, phosphorus and nitrogen metabolism of a breast-fed rachitic infant and its response to vitamin $D$ administration to the mother

\begin{tabular}{|c|c|c|c|c|c|c|c|c|c|c|c|c|c|c|c|c|c|c|c|c|}
\hline \multirow{2}{*}{$\begin{array}{l}\text { Date } \\
1937\end{array}$} & \multirow{2}{*}{$\begin{array}{l}\text { Pe- } \\
\text { riod } \\
\text { four- } \\
\text { day }\end{array}$} & \multirow{2}{*}{$\begin{array}{c}\text { Breast } \\
\text { milk } \\
\text { intake }\end{array}$} & \multicolumn{5}{|c|}{ Calcium, average per day } & \multicolumn{5}{|c|}{ Phosphorus, average per day } & \multicolumn{5}{|c|}{ Nitrogen, average per day } & \multicolumn{2}{|c|}{ Serum } & \multirow{2}{*}{$\begin{array}{l}\text { Body } \\
\text { weight }\end{array}$} \\
\hline & & & $\begin{array}{l}\text { In- } \\
\text { take }\end{array}$ & Urine & Stool & $\begin{array}{l}\text { Bal- } \\
\text { ance }\end{array}$ & $\begin{array}{l}\text { Re- } \\
\text { ten- } \\
\text { tion }\end{array}$ & $\begin{array}{l}\text { In- } \\
\text { take }\end{array}$ & Urine & Stool & $\begin{array}{l}\text { Bal- } \\
\text { ance }\end{array}$ & $\begin{array}{l}\mathrm{Re}- \\
\text { ten- } \\
\text { tion }\end{array}$ & $\underset{\text { take }}{\text { In- }}$ & Urine & Stool & $\begin{array}{l}\text { Bal- } \\
\text { ance }\end{array}$ & \begin{tabular}{|l|} 
Re- \\
ten- \\
tion
\end{tabular} & $\begin{array}{l}\text { Cal- } \\
\text { cium }\end{array}$ & $\begin{array}{l}\text { Phos- } \\
\text { phorus }\end{array}$ & \\
\hline & & $c c$. & mgm. & $m g m$. & mgm. & mgm. & $\begin{array}{l}\text { per } \\
\text { cent }\end{array}$ & mgm. & $m g m$. & mgm. & $m g m$. & $\begin{array}{l}\text { per } \\
\text { cent }\end{array}$ & mgm. & mgm. & $m g m$. & $\mathbf{m g m}$ & $\begin{array}{c}\text { per } \\
\text { cent }\end{array}$ & $\begin{array}{c}\text { mgm. } \\
\text { per } \\
\text { cent }\end{array}$ & $\begin{array}{c}\text { mgm. } \\
\text { per } \\
\text { cent }\end{array}$ & kgm. \\
\hline $\begin{array}{l}\text { IV } 6-9 \\
\text { IV } 18-21 \\
\text { IV 22-25 } \\
\text { IV26-29 } \\
\text { IV30-V3 } \\
\text { V 4-7 } \\
\text { V 8-11 } \\
\text { V } 12-15 \\
\text { V16-19 } \\
\text { V20-23 }\end{array}$ & $\begin{array}{l}1 \\
4 * \\
5 \\
6 \\
7 \\
8 \\
9 \\
10 \\
11 \\
12\end{array}$ & $\begin{array}{l}656 \\
648 \\
720 \\
720 \\
810 \\
810 \\
810 \\
810 \\
810 \\
900\end{array}$ & $\begin{array}{l}232 \\
247 \\
233 \\
229 \\
235 \\
259 \\
260 \\
264 \\
259 \\
289\end{array}$ & $\begin{array}{r}\mathbf{5} \\
\mathbf{0} \\
\mathbf{0} \\
\mathbf{0} \\
\mathbf{3} \\
\mathbf{7} \\
\mathbf{1 8} \\
\mathbf{2 5} \\
\mathbf{3 1} \\
\mathbf{3 2}\end{array}$ & $\begin{array}{r}105 \\
156 \\
165 \\
131 \\
79 \\
51 \\
51 \\
28 \\
27 \\
24\end{array}$ & $\begin{array}{l}+122 \\
+91 \\
+68 \\
+98 \\
+153 \\
+201 \\
+191 \\
+211 \\
+201 \\
+233\end{array}$ & $\begin{array}{l}48 \\
37 \\
29 \\
43 \\
65 \\
78 \\
74 \\
80 \\
78 \\
81\end{array}$ & $\begin{array}{l}106 \\
118 \\
113 \\
121 \\
128 \\
122 \\
131 \\
127 \\
121 \\
144\end{array}$ & $\begin{array}{r}46 \\
22 \\
16 \\
5 \\
5 \\
2 \\
2 \\
2 \\
1 \\
1\end{array}$ & $\begin{array}{l}26 \\
19 \\
25 \\
33 \\
51 \\
13 \\
14 \\
13 \\
14 \\
15\end{array}$ & $\begin{array}{r}+34 \\
+77 \\
+72 \\
+83 \\
+72 \\
+107 \\
+115 \\
+112 \\
+106 \\
+128\end{array}$ & $\begin{array}{l}31 \\
65 \\
61 \\
68 \\
56 \\
88 \\
88 \\
88 \\
88 \\
89\end{array}$ & $\begin{array}{l}1.18 \\
1.34 \\
1.20 \\
1.28 \\
1.34 \\
1.53 \\
1.60 \\
1.54 \\
1.54 \\
1.48\end{array}$ & $\begin{array}{l}0.61 \\
0.33 \\
0.37 \\
0.43 \\
0.38 \\
0.35 \\
0.44 \\
0.50 \\
0.45 \\
0.42\end{array}$ & \begin{tabular}{|l|}
0.24 \\
0.26 \\
0.29 \\
0.29 \\
0.28 \\
0.26 \\
0.32 \\
0.28 \\
0.27 \\
0.30
\end{tabular} & $\begin{array}{r}+0.33 \\
+0.75 \\
+0.54 \\
+0.56 \\
+0.68 \\
+0.92 \\
+0.84 \\
+0.76 \\
+0.82 \\
+0.76\end{array}$ & $\begin{array}{l}28 \\
56 \\
45 \\
44 \\
51 \\
60 \\
52 \\
49 \\
53 \\
51\end{array}$ & 11.32 & 5.61 & $\begin{array}{l}4.97 \\
4.92 \\
4.97 \\
5.18 \\
5.15 \\
5.34 \\
5.53 \\
5.55 \\
\mathbf{5 . 7 0} \\
\mathbf{5 . 9 4}\end{array}$ \\
\hline
\end{tabular}

* Mother starting to receive Vigantol 1 cc. per day from this period on.

day was given from periods 5 to 15 , and from periods 16 to 20 the dosage was raised to $1.5 \mathrm{cc}$. or 18,000 international units per day. All this vitamin $D$ supply did not seem to produce obvious changes in the calcium metabolism, balances being approximately even on levels of intake varying from 1,000 to $2,000 \mathrm{mgm}$. No significant amounts of calcium appeared in the urine, the paths of excretion being mainly through the bowel and breasts during most of the periods. The absence of calcium in the urine was possibly related to the very high phosphorus intake (periods 7 to 11 ). While no substantial gain in calcium or phosphorus was evident after vitamin D administration, such therapy was probably important in enabling the subject to maintain mineral balance in spite of heightened requirements during lactation.

The phosphorus metabolism followed closely the calcium metabolism, although the urinary tract constituted by far the largest channel of phosphorus elimination. Nitrogen gain prevailed during most of the experimental periods. Serum calcium and inorganic phosphorus showed no remarkable changes, although a slight ascending tendency was discernible in both, as time went on.

From the observations on this experimental subject, it may be stated that a normal woman with intact skeletal calcification is able to maintain herself in calcium and phosphorus balance in the face of mineral stress incident to lactation, provided that the level of intake is sufficiently high and vitamin D supply is adequate. However, significantly positive balance is not expected, as there is presumably no need for it.

Case $3 b$. Infant T. N. T. This infant, born of a mother having osteomalacia and tetany, was admitted at the age of three months. He presented evidence of moderate rickets with very low serum calcium and high inorganic phosphorus. During periods A, B. and C 


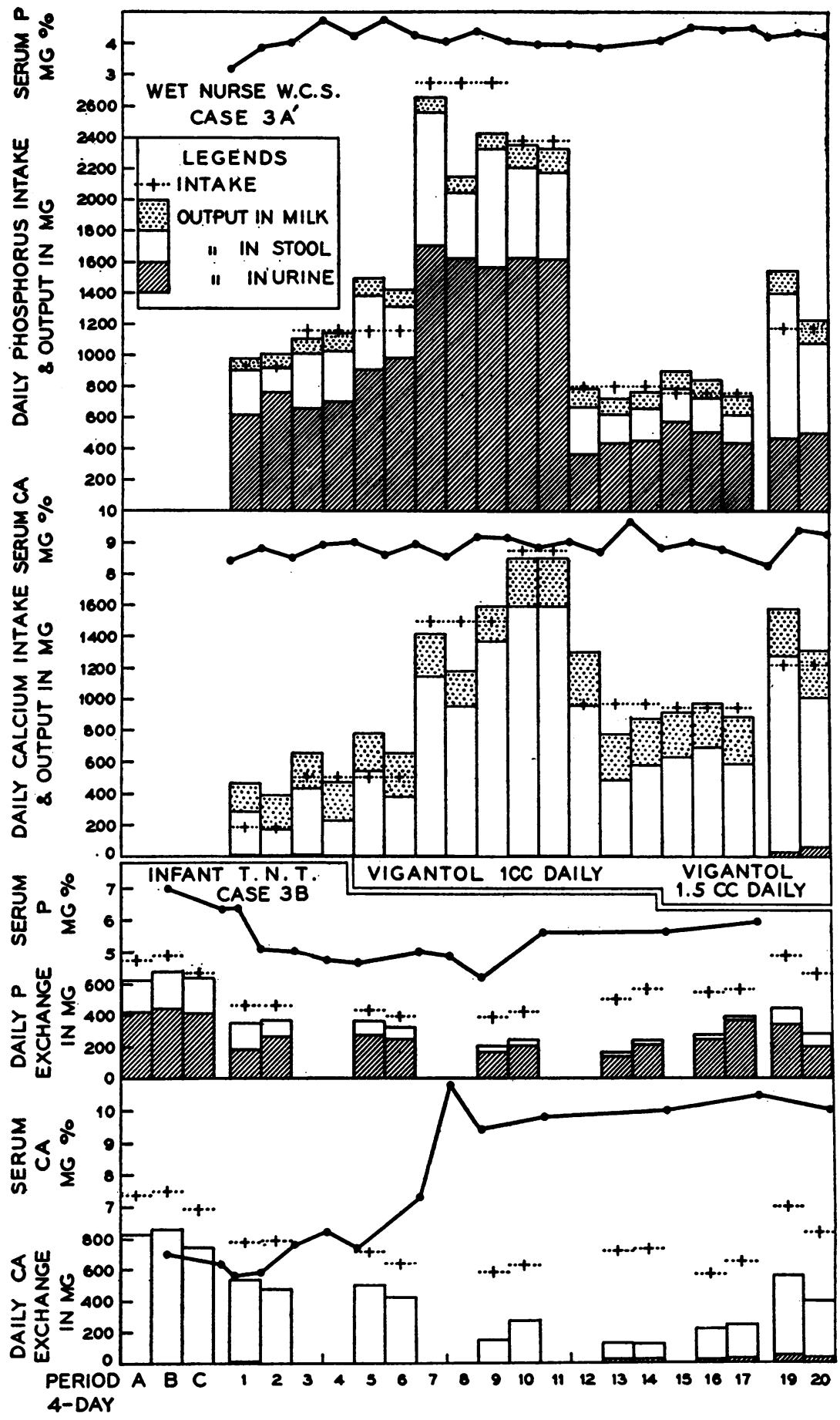

Fig. 3. Calcium and Phosphorus Metabolism of Cases 3A' and 3B

The wet nurse was presumably normal, although the Vigantol given probably helped her in maintaining mineral balance. The infant with rickets and tetany did poorly on Klim and on breast milk of the wet nurse until vitamin D was given to the latter. Then remarkably good mineral retention occurred in the infant. 
TABLE VII

Wet nurse W. C.S. Case 3a'. Calcium, phosphorus and nitrogen metabolism of a presumably normal lactating woman before and after vitamin $D$ therapy

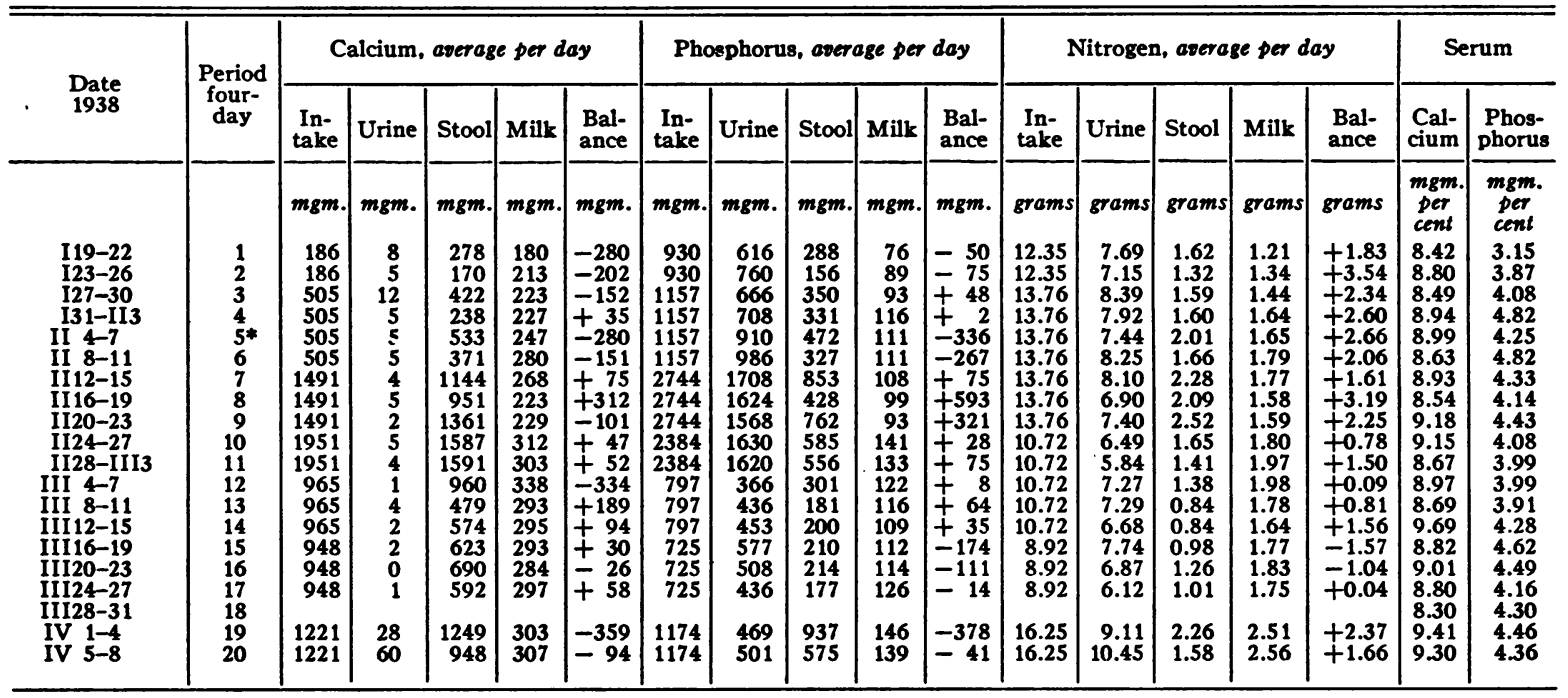

- Vigantol 1 cc. daily starting from this period on.

TABLE VIII

Infant T.N.T. Case 3b. Calcium, phosphorus and nitrogen metabolism of a rachitic infant on cow's milk, breast milk from the wet nurse and combinations thereof

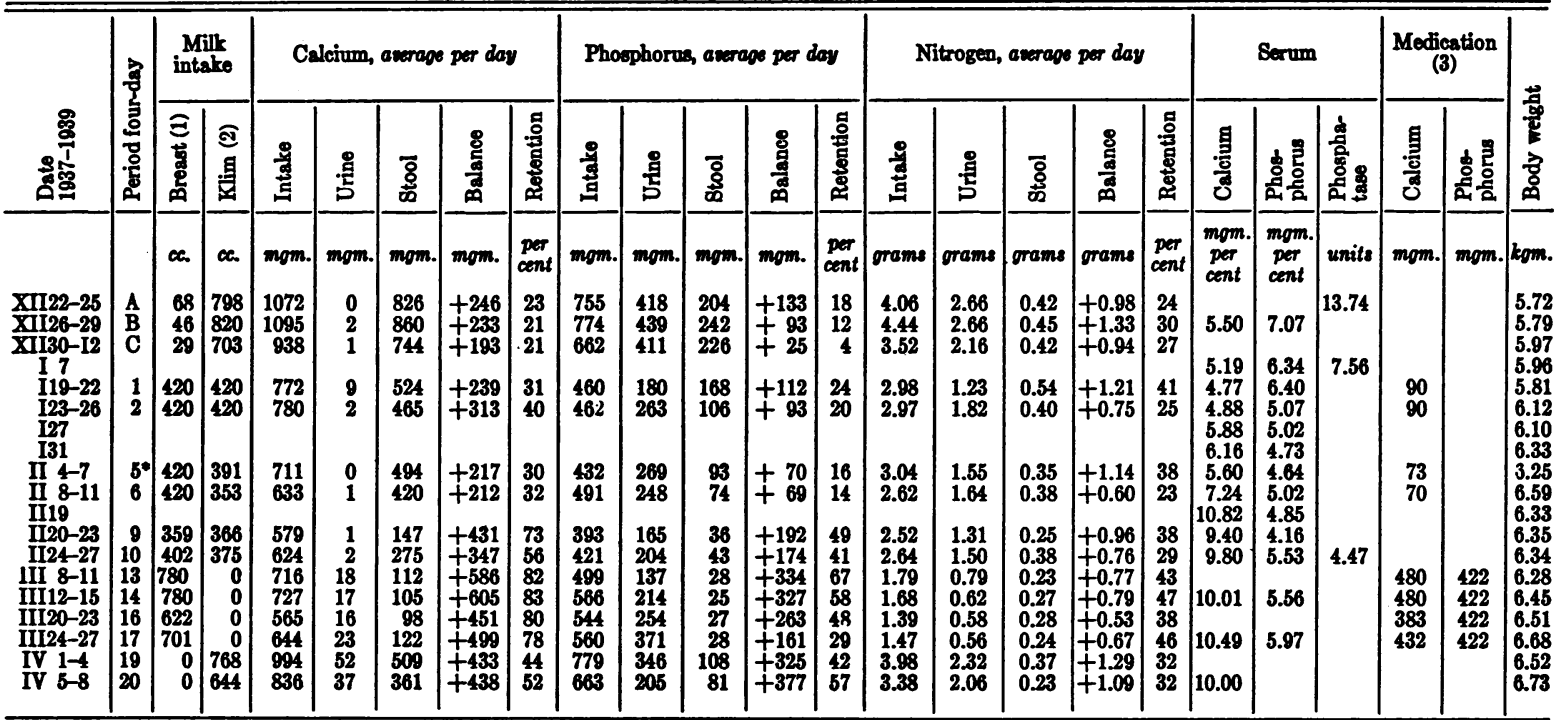

(1) The small amounts of breast milk given during periods $A, B$ and $C$ were from the mother (Case $3 a$ ), and the breast milk for the rest of the periods was supplied by the wet nurse (Case 3a', Table II).

(2) "Klim" used for periods A, B and C was analyzed to contain $132.5 \mathrm{mgm}$. calcium, $93.9 \mathrm{mgm}$. phosphorus and 0.492 grams nitrogen per $100 \mathrm{cc}$.; while that used for the remaining periods, $129.2 \mathrm{mgm}$. calcium, $94.4 \mathrm{mgm}$. phosphorus and 0.484 grams nitrogen per $100 \mathrm{cc}$. The formula was made up by dissolving one part of Klim whole milk powder in eight parts of water.

(3) Calcium given in periods 1-2 was in the form of 10 per cent gluconate intramuscularly; that in periods 5 and 6 , 3 per cent gluconate by mouth; and that in periods $13-17,7.7$ per cent lactate by mouth. Phosphorus was given as disodium phosphate solution per os.

* Wet nurse starting to receive vitamin D from this period. 
(Figure 3 and Table VIII) while on a Klim formula (with small amounts of breast milk from the mother) providing about $1,000 \mathrm{mgm}$. of calcium, large amounts of calcium came out in the stools, leaving a net retention of only 21 to 23 per cent of the intake. Phosphorus retention was even poorer, being 4 to 18 per cent. Serum calcium went down to as low as $4.77 \mathrm{mgm}$. per cent, whereupon convulsive seizures occurred. Evidently the infant, like the mother, was markedly deficient in vitamin $D$.

After the manifest tetany was brought under control by means of parenteral calcium therapy, metabolic observations were resumed, and breast feeding from the wet nurse was begun. Periods 1 and 2 served as control for a regimen of "half breast milk and half Klim formula" furnishing from 600 to $800 \mathrm{mgm}$. of calcium and from 400 to $500 \mathrm{mgm}$. of phosphorus. On this regimen the retention of both elements was distinctly poor, though slightly better than during periods $\mathrm{A}$ to $\mathrm{C}$ when $\mathrm{Klim}$ constituted almost the sole source of nutrients. This indicates that the wet nurse prior to vitamin D supplements, while capable of maintaining her skeleton intact for a time, was probably unable to secrete milk of sufficiently high antirachitic potency to correct the metabolic defect of the infant.

From period 5 on the wet nurse received vitamin D. The effect of this supplement to the milk provider on the infant's metabolism was not evident during the first 2 periods (periods 5 and 6 ), but subsequently considerable improvement was noticed. During periods 9 and 10, calcium retention rose to 56 to 73 per cent and phosphorus retention to 41 to 49 per cent. The best performance came during periods $13,14,16$ and 17, when breast milk from the wet nurse alone was fed with additions of calcium lactate and disodium phosphate to maintain the calcium and phosphorus intake. Here the average calcium retention of the 4 periods amounted to 81 per cent, and the average phosphorus retention to 50 per cent of the intake. The high degree of retention of calcium was brought about entirely by a reduction in the stool elimination, while that of phosphorus was caused by a reduction in both the urine and stool excretion.

The last 2 periods were devoted to a study of the effects of feeding $\mathrm{Klim}$ alone comparable to the regimen in periods $\mathrm{A}$ to $\mathrm{C}$. While vitamin $\mathrm{D}$ was still operative, as it was presumably so during periods 19 and 20 , both calcium and phosphorus retention were decidedly better than during periods $A$ to $C$ when marked vitamin $D$ deficiency had existed. However, the degree of retention was not as good as during the exclusive breast-feeding periods, possibly suggesting certain peculiarities in the cow's milk that rendered its mineral contents less readily absorbable.

The behavior of serum calcium is worth noting. After it reached its lowest ebb with the onset of convulsions, parenteral calcium was capable of raising it only just enough to stop the convulsions; but with the feeding of "vitaminized" breast milk it rose precipitously to normal in the course of twelve days, and remained so throughout the balance of the experiment. Serum inorganic phosphorus, high to start with, went down to below normal when serum calcium reached the normal level, and subsequently it also rose to normal.

Coinciding with the correction of the biochemical abnormalities, there was clinical improvement as well as roentgenologic evidence of healing of the rachitic bone changes in the course of a little over two months.

Case 4a. Mother W. H. S. This patient had active osteomalacia with slightly low serum calcium and markedly low serum inorganic phosphorus. She was admitted at the eighth month of pregnancy, and metabolic observation during the latter part of gestation showed that even balances were obtained on high levels of calcium intake and that the administration of Vigantol, $5 \mathrm{cc}$. daily for four days, was followed by progressive and marked retention of calcium and phosphorus, and a return of serum calcium and inorganic phosphorus to normal. The Vigantol given for the above-stated period, together with cod liver oil in $30 \mathrm{cc}$. daily doses for six days immediately postpartum, constituted the only supply of vitamin D prior to the studies on lactation.

As shown in Figure 4 and Table IX, metabolic observations, begun seventeen days postpartum, were continued for 26 four-day periods on intakes of calcium ranging from 1,407 to $1,656 \mathrm{mgm}$. per day. No vitamin $D$ was supplied until the 19th period when Vigantol was started in daily doses of $2 \mathrm{cc}$. or 24,000 international units and continued for the remainder of the experiment. During the first 18 periods without vitamin $\mathrm{D}$, the calcium balances showed considerable fluctuation. However, the trend is one of progressive loss of calcium from the body. If the 18 periods are divided into 3 series of 6 periods each, and the balances in each series averaged, one obtains a daily calcium balance of $+9 \mathrm{mgm} .,-19$ mgm. and $-70 \mathrm{mgm}$. for periods 1 to 6,7 to 12 and 13 to 18 , respectively. This progressive weakening of calcium balance indicates most probably that the limited amount of vitamin $D$ received prior to the studies was gradually being depleted in the course of three or four months. Another sign of vitamin D depletion, or rather deficient intestinal absorption, is the diminution and disappearance of urinary calcium with a correspondingly increased stool calcium.

After vitamin D therapy (beginning with period 19), the situation was entirely reversed. Stool calcium gradually decreased while urinary calcium returned. But the conservation through the bowel was much greater in extent than the loss through the urinary tract and, as a result, the balance became increasingly positive. The average daily calcium retention for the 8 periods amounted to $133 \mathrm{mgm}$. Thus vitamin $\mathrm{D}$ administration during lactation in a woman with skeletal decalcification, similar to Case $2 \mathrm{a}$, was capable of conserving the metabolism of calcium to such an extent as to enable her not only to meet the strenuous requirements of lactation, but 


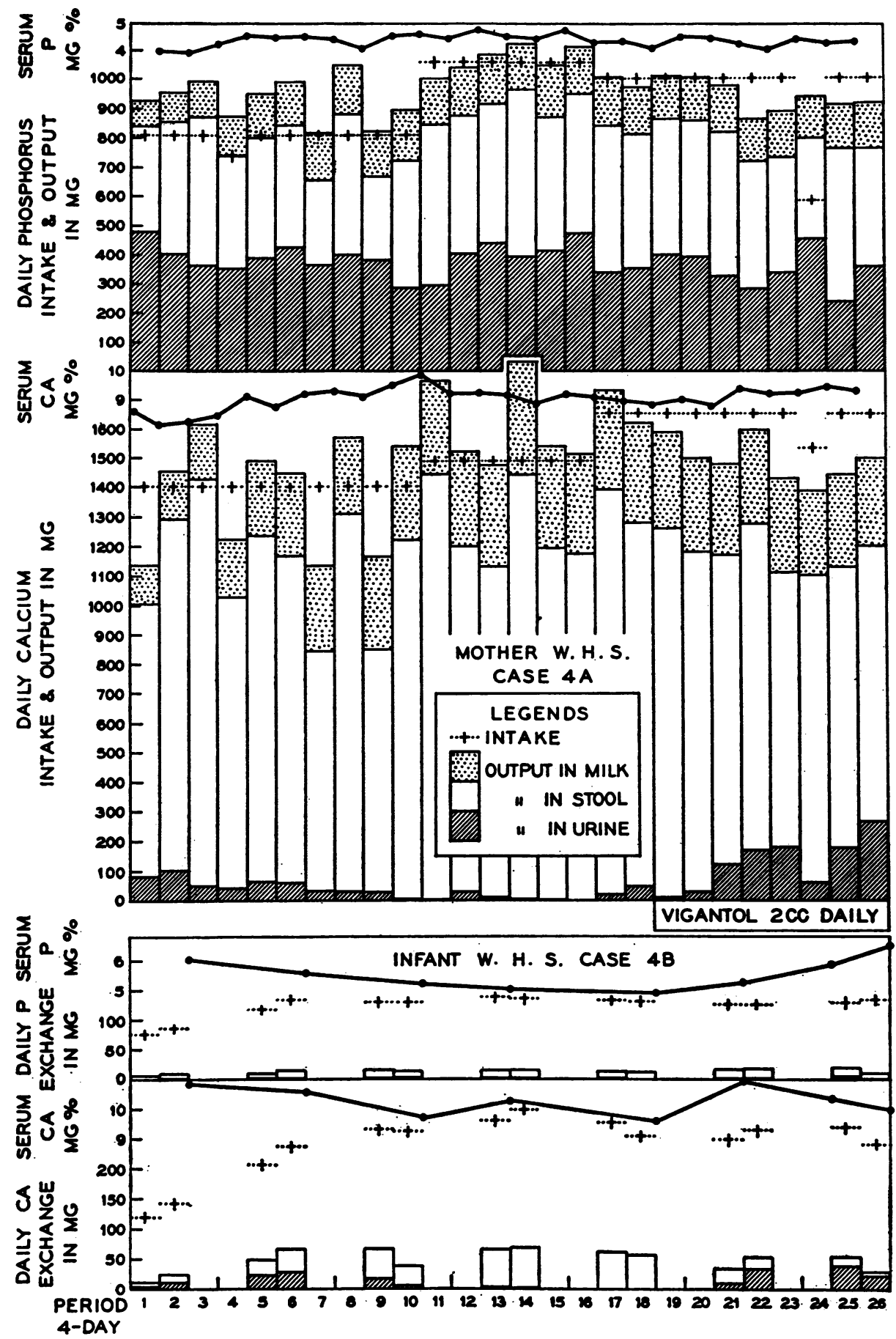

Fig. 4. Calcium and Phosphorus Metabolism of Cases 4A and 4B

The mother with osteomalacia had a limited amount of vitamin $\mathrm{D}$ prior to study, but showed increasing mineral loss as observation proceeded until Vigantol was given. The infant exhibited good retention of calcium and phosphorus throughout, but a decrease, and later, disappearance of urinary calcium with corresponding increase of fecal calcium occurred while the mother was being depleted of vitamin D. Reinstitution of vitamin D therapy in the mother brought about a reversal in the partition of calcium between urinary and fecal elimination. 
TABLE IX

Mother W. H.S. Case 4a. Calcium, phosphorus and nitrogen metabolism in a case of osteomalacia during lactation at various states of vitamin $D$ nutrition

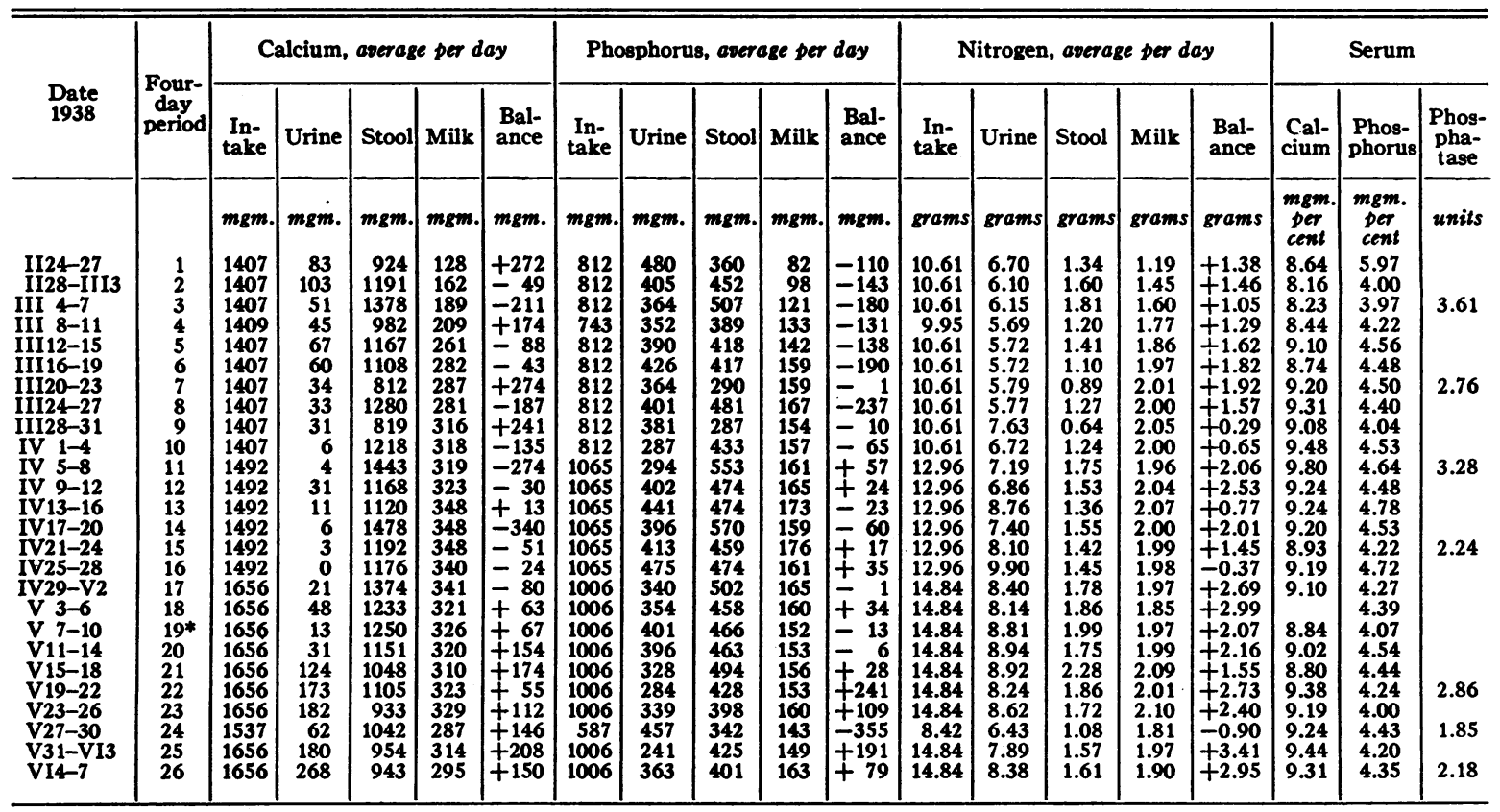

* Vigantol 2 cc. daily starting from this period.

also to retain considerable amounts of the mineral for the replenishment of the skeletal store.

Phosphorus balances were mainly negative, especially during periods 1 to 10 when the intake was relatively low. But after vitamin D therapy substantial amounts of phosphorus were retained. Serum calcium and inorganic phosphorus were maintained at fairly steady levels.

Case 4b. Infant W. H.S. This was a normal baby. Although his mother (Case 4a) had active osteomalacia during pregnancy, the vitamin $\mathrm{D}$ given during the latter part of gestation, albeit limited in amount, might have contributed to the relative wellbeing of the infant from the standpoint of mineral metabolism. While exclusively fed on the mother's milk, the calcium, phosphorus and nitrogen balances of the infant were studied pari passu with those of the mother, although with him 2 periods of actual study were alternated with 2 "rest" periods. Comparable to the normal infant (Case $1 \mathrm{~b}$ ) and the 2 rachitic infants (Cases $2 b$ and $3 b$ ) following feeding with breast milk "vitaminized" via the mother, this infant showed such avidity in retaining calcium and phosphorus that he left only small amounts of these elements to be eliminated in the urine and stool. As shown in Figure 4 and Table $X$ approximately 80 per cent of the calcium and 90 per cent of the phosphorus in the milk were retained.

As the mother was being depleted of vitamin D, the infant began to show a slight decrease in calcium retention (periods 13 to 18 ). What is more striking is the behavior of the urinary and stool calcium. As impoverishment of vitamin $\mathrm{D}$ proceeded in the mother, there was in the infant a progressive decrease in the urinary calcium to the point of disappearance, coinciding with a steady increase in the stool calcium.

This phenomenon was interpreted as an early sign of vitamin $\mathrm{D}$ deficiency, because when the mother began to be replenished with vitamin $D$, the infant showed a return of urinary calcium with a corresponding decrease of stool calcium. The net gain of calcium was somewhat better during the last 4 periods (periods 21 to 22 and 25 to 26) of observation when the mother was receiving Vigantol.

It is of interest to note that throughout the entire 26 periods, the phosphorus retention was maintained at the uniform high level of 90 per cent with very little variation in the partition of phosphorus between the urine and the stool, suggesting that phosphorus metabolism was possibly a less sensitive index of vitamin $D$ nutrition than calcium metabolism.

Both the serum calcium and inorganic phosphorus were maintained within normal limits throughout the periods of observation. However, there seemed to be a decline in both elements toward the end of the depletion period in the mother, with a return to the initial levels subsequently when the mother was being replenished with vitamin D.

Roentgenograms of the wrists taken periodically revealed that the epiphyseal lines, normal to start with, began to be fuzzy with "lipping" at the end of the period of 
depletion in the mother. After the infant had received for a month breast milk from the mother being given vitamin $\mathrm{D}, \mathbf{x}$-ray showed improvement in what were considered to be the early changes of rickets.

\section{DISCUSSION}

Observations made simultaneously on the calcium, phosphorus and nitrogen metabolism of the lactating mother and of the breast-milk-fed infant of the type recorded in the present communication have not been reported in the literature as far as we are aware. Yet such experiments are of importance in throwing light on the nature and extent of the relationship between the maternal and infantile nutrition by way of the breast milk. From the results presented, several points of interest may be mentioned.

Maternal metabolism during lactation. It is generally accepted that considerable difficulty exists in maintaining women in mineral balance during lactation. Hunscher (10) and Hummel and associates (9) failed to maintain actively nursing women in calcium balance on very high intake ( 3 to 4 grams per day) during the early part of lactation. Only during late lactation, when milk flow diminished, was calcium stored (5). Supplementing the usual home diets with cod liver oil, although improving the calcium balance, did not always change a negative to a positive balance (15). Garry and Stiven (6), who have reviewed the recent literature on dietary re- quirements in pregnancy and lactation, recommend 1 to 2 grams of calcium for milk yields of from 500 to $1,000 \mathrm{cc}$. and calcium contents from 20 to $30 \mathrm{mgm}$. per $100 \mathrm{cc}$. milk.

To insure the proper utilization of the aboverecommended amount of calcium intake, vitamin $\mathrm{D}$ must be added. Thus all the 4 lactating women studied maintained themselves in calcium balance on intakes between 1 to 2 grams when vitamin D was operative. These data are especially significant when it is remembered that they were obtained from women in early lactation with milk yields exceeding one liter a day and calcium content more than $25 \mathrm{mgm}$. per $100 \mathrm{cc}$. On the other hand, when vitamin $\mathrm{D}$ was deficient (Case $2 \mathrm{a}$ ), or being depleted (Case 4a), negative balance prevailed. Therefore, some of the reported difficulties in maintaining calcium balance in lactation on relatively high intake can be as justly attributed to vitamin $\mathrm{D}$ undernutrition as to the heightened requirements of this phase of the reproductive cycle.

To the woman with prior vitamin $\mathrm{D}$ and calcium deficiency, as in osteomalacia, the administration of vitamin $\mathrm{D}$ has the added importance of making it possible for her to store calcium for her skeletal replenishment in the face of extra drain of lactation. This is amply illustrated by the data obtained from Cases $2 \mathrm{a}$ and $4 \mathrm{a}$.

The situation in late lactation, when the milk flow diminishes, may be less stringent. Of the

TABLE $\mathbf{X}$

Infant W.H.S. Case 4b. Calcium, phosphorus and nitrogen metabolism of a presumably normal breast-fed infant showing changes due to the varying state of vitamin $D$ nutrition in the mother

\begin{tabular}{|c|c|c|c|c|c|c|c|c|c|c|c|c|c|c|c|c|c|c|c|c|c|}
\hline \multirow{2}{*}{$\begin{array}{l}\text { Date } \\
1839\end{array}$} & \multirow{2}{*}{$\begin{array}{l}\text { Period } \\
\text { four- } \\
\text { day }\end{array}$} & \multirow{2}{*}{$\begin{array}{l}\text { Breast } \\
\text { milk } \\
\text { intake }\end{array}$} & \multicolumn{5}{|c|}{ Calcium, average per day } & \multicolumn{5}{|c|}{ Phosphorus, aserage per day } & \multicolumn{5}{|c|}{ Nitrogen, aserage per day } & \multicolumn{3}{|c|}{ Serum } & \multirow{2}{*}{$\begin{array}{l}\text { Body } \\
\text { weight }\end{array}$} \\
\hline & & & $\underset{\text { take }}{\text { In- }}$ & Urine & Stool & $\begin{array}{l}\text { Bal- } \\
\text { ance }\end{array}$ & $\mid \begin{array}{c}\text { Ro- } \\
\text { ten- } \\
\text { tion }\end{array}$ & $\underset{\text { take }}{\text { In- }}$ & Urine & Stool & $\begin{array}{l}\text { Bal- } \\
\text { ance }\end{array}$ & $\begin{array}{l}\text { Ro- } \\
\text { ten- } \\
\text { tion }\end{array}$ & $\underset{\text { take }}{\text { In- }}$ & Urine & Stool & $\begin{array}{l}\text { Bal- } \\
\text { ance }\end{array}$ & $\mid \begin{array}{c}\text { Re- } \\
\text { ten- } \\
\text { tion }\end{array}$ & çat- & $\begin{array}{l}\text { Phos- } \\
\text { phorus }\end{array}$ & $\begin{array}{c}\text { Phospha- } \\
\text { tase }\end{array}$ & \\
\hline $\begin{array}{l}\text { II24-27 } \\
\text { II28-III3 } \\
\text { III12-15 } \\
\text { III16-19 } \\
\text { III28-31 } \\
\text { IV 1-4 } \\
\text { IV13-16 } \\
\text { IV17-20 } \\
\text { IV20-V2 } \\
\text { V 3-6 } \\
\text { V15-18 } \\
\text { V19-22 } \\
\text { V31-VI3 } \\
\text { VI 4-7 }\end{array}$ & $\begin{array}{r}1 \\
2 \\
5 \\
6 \\
9 \\
10 \\
13 \\
14 \\
17 \\
18 * \\
21 \\
22 \\
25 \\
26\end{array}$ & $\begin{array}{r}c c . \\
\\
466 \\
510 \\
720 \\
780 \\
900 \\
900 \\
945 \\
1020 \\
1020 \\
1020 \\
1020 \\
1020 \\
1080 \\
1080\end{array}$ & $\begin{array}{l}\text { mgm. } \\
\\
120 \\
142 \\
217 \\
237 \\
266 \\
263 \\
280 \\
300 \\
277 \\
255 \\
249 \\
266 \\
271 \\
243\end{array}$ & $\begin{array}{r}\text { mgm. } \\
4 \\
4 \\
12 \\
23 \\
28 \\
17 \\
6 \\
3 \\
1 \\
1 \\
0 \\
9 \\
34 \\
39 \\
30\end{array}$ & \begin{tabular}{|r|}
$m g m$ \\
\\
8 \\
12 \\
25 \\
39 \\
50 \\
32 \\
64 \\
67 \\
62 \\
57 \\
25 \\
19 \\
15 \\
7
\end{tabular} & $\begin{array}{r}\text { mom. } \\
\\
+108 \\
+118 \\
+169 \\
+170 \\
+199 \\
+225 \\
+213 \\
+232 \\
+214 \\
+198 \\
+215 \\
+213 \\
+217 \\
+206\end{array}$ & $\begin{array}{c}\text { per } \\
\text { cent } \\
90 \\
80 \\
83 \\
79 \\
72 \\
75 \\
86 \\
76 \\
77 \\
77 \\
78 \\
86 \\
80 \\
80 \\
85\end{array}$ & $\begin{array}{r}\text { mom. } \\
77 \\
86 \\
118 \\
134 \\
129 \\
131 \\
139 \\
137 \\
134 \\
131 \\
126 \\
126 \\
129 \\
135\end{array}$ & $\begin{array}{c}\text { mom. } \\
\\
0 \\
1 \\
2 \\
2 \\
1 \\
2 \\
1 \\
1 \\
0 \\
1 \\
1 \\
3 \\
5 \\
2\end{array}$ & \begin{tabular}{|r|}
$m g m$ \\
\\
6 \\
9 \\
8 \\
13 \\
15 \\
11 \\
14 \\
14 \\
13 \\
11 \\
16 \\
15 \\
14 \\
10
\end{tabular} & $\begin{array}{r}m g m . \\
\\
+71 \\
+76 \\
+108 \\
+1119 \\
+113 \\
+118 \\
+124 \\
+122 \\
+121 \\
+119 \\
+109 \\
+108 \\
+110 \\
+123\end{array}$ & $\begin{array}{c}\text { per } \\
\text { cent } \\
92 \\
82 \\
88 \\
92 \\
89 \\
88 \\
90 \\
89 \\
89 \\
90 \\
91 \\
94 \\
93 \\
92 \\
91\end{array}$ & $\begin{array}{c}\text { grams } \\
\\
1.07 \\
1.19 \\
1.55 \\
1.66 \\
1.73 \\
1.67 \\
1.67 \\
1.72 \\
1.56 \\
1.51 \\
1.68 \\
1.65 \\
1.70 \\
1.57\end{array}$ & \begin{tabular}{|l|} 
grams \\
\\
0.35 \\
0.82 \\
0.55 \\
0.73 \\
0.62 \\
0.61 \\
0.62 \\
0.62 \\
0.57 \\
0.57 \\
0.47 \\
0.55 \\
0.67 \\
0.55
\end{tabular} & \begin{tabular}{|l} 
grams \\
\\
0.17 \\
0.20 \\
0.21 \\
0.25 \\
0.24 \\
0.19 \\
0.24 \\
0.22 \\
0.24 \\
0.17 \\
0.25 \\
0.27 \\
0.24 \\
0.14
\end{tabular} & $\begin{array}{r}\text { grams } \\
\\
+0.55 \\
+0.17 \\
+0.79 \\
+0.68 \\
+0.87 \\
+0.87 \\
+0.81 \\
+0.88 \\
+0.75 \\
+0.77 \\
+0.86 \\
+0.83 \\
+0.79 \\
+0.88\end{array}$ & $\begin{array}{c}p e r \\
\text { cent } \\
51 \\
14 \\
51 \\
41 \\
50 \\
52 \\
48 \\
51 \\
48 \\
51 \\
51 \\
50 \\
46 \\
56\end{array}$ & $\begin{array}{c}\text { mgm. } \\
\text { per } \\
\text { cent } \\
\\
10.88 \\
10.55 \\
9.70 \\
10.25 \\
9.58 \\
11.17 \\
10.34 \\
10.01\end{array}$ & $\begin{array}{c}\text { mom. } \\
\text { per } \\
\text { cent }\end{array}$ & $\begin{array}{r}8.21 \\
17.00 \\
15.42\end{array}$ & $\begin{array}{l}\text { kgm. } \\
\\
3.01 \\
3.08 \\
3.57 \\
3.70 \\
4.15 \\
4.40 \\
4.85 \\
4.97 \\
5.67 \\
5.76 \\
6.24 \\
6.39 \\
6.80 \\
6.77\end{array}$ \\
\hline
\end{tabular}

* Mother starting to receive Vigantol $2 \mathrm{cc}$. per day right after the completion of this period. 
TABLE XI

Data selected and averaged from Tables IV, VI, VIII and $X$ to show the calcium retention of the infants in the present study for comparison with the maximum recorded retention of breast-fed infants compiled from the literature by Leitch (11)

\begin{tabular}{|c|c|c|c|c|c|c|c|c|c|c|c|c|c|c|c|c|c|c|c|c|}
\hline \multirow[b]{2}{*}{ Age } & \multicolumn{4}{|c|}{ Leitch } & \multicolumn{4}{|c|}{ Case 1b } & \multicolumn{4}{|c|}{ Case 2b } & \multicolumn{4}{|c|}{ Case 3b } & \multicolumn{4}{|c|}{ Case 4b } \\
\hline & $\begin{array}{l}\text { In- } \\
\text { take }\end{array}$ & $\begin{array}{l}\text { Bal- } \\
\text { ance }\end{array}$ & $\begin{array}{c}\text { Re- } \\
\text { ten- } \\
\text { tion } \\
\end{array}$ & $\begin{array}{c}\text { Ideal } \\
\text { reten } \\
\text { tion } \\
\end{array}$ & $\begin{array}{c}\text { Pe- } \\
\text { riod }\end{array}$ & $\begin{array}{c}\text { In- } \\
\text { take }\end{array}$ & $\begin{array}{c}\text { Bal- } \\
\text { ance }\end{array}$ & $\begin{array}{c}\mathrm{Re}- \\
\text { ten- } \\
\text { tion }\end{array}$ & $\begin{array}{c}\mathrm{Pe}- \\
\text { riod }\end{array}$ & $\begin{array}{c}\text { In- } \\
\text { take }\end{array}$ & $\begin{array}{l}\text { Bal- } \\
\text { ance }\end{array}$ & $\begin{array}{c}\text { Re- } \\
\text { ten- } \\
\text { tion }\end{array}$ & Period & $\begin{array}{l}\text { In- } \\
\text { take }\end{array}$ & \begin{tabular}{|c|} 
Bal- \\
ance
\end{tabular} & $\left|\begin{array}{c}\text { Re- } \\
\text { ten- } \\
\text { tion }\end{array}\right|$ & Period & $\begin{array}{c}\text { In- } \\
\text { take }\end{array}$ & $\begin{array}{c}\mathrm{Bal}- \\
\text { ance }\end{array}$ & $\begin{array}{c}\mathrm{Re}- \\
\text { ten- } \\
\text { tion }\end{array}$ \\
\hline months & $m g m$. & mgm. & $\begin{array}{l}\text { per } \\
\text { cent }\end{array} \mid$ & mgm. & & $m g m$. & $m g m$. & $\begin{array}{l}\text { per } \\
\text { cent }\end{array}$ & & mgm. & mgm. & $\begin{array}{l}\text { per } \\
\text { cent }\end{array} \mid$ & & mgm. & mgm. & $\begin{array}{l}\text { per } \\
\text { cent }\end{array} \mid$ & & mgm. & $m g m$. & $\begin{array}{l}\text { per } \\
\text { cent }\end{array}$ \\
\hline $\begin{array}{l}0-1 \\
1-2 \\
2-3 \\
3-4 \\
4-5 \\
5-6\end{array}$ & $\begin{array}{l}208 \\
127 \\
149 \\
235 \\
236 \\
221\end{array}$ & $\begin{array}{r}82 \\
85 \\
102 \\
109 \\
142 \\
65\end{array}$ & $\begin{array}{l}39 \\
67 \\
68 \\
46 \\
60 \\
29\end{array}$ & \begin{tabular}{|l|}
130 \\
310 \\
250 \\
240 \\
220 \\
170
\end{tabular} & $\begin{array}{l}3-4 \\
5-9\end{array}$ & $\begin{array}{l}290 \\
336\end{array}$ & $\begin{array}{l}220 \\
255\end{array}$ & \begin{tabular}{|l|}
76 \\
76
\end{tabular} & $8-12$ & 266 & 207 & 78 & $13-17$ & $663 t$ & 535 & 81 & $\begin{array}{c}1-2 \\
5-10 \\
13-18 * \\
21-26\end{array}$ & $\begin{array}{l}131 \\
246 \\
278 \\
257\end{array}$ & $\begin{array}{l}113 \\
191 \\
228 \\
213\end{array}$ & $\begin{array}{l}86 \\
78 \\
82 \\
83\end{array}$ \\
\hline
\end{tabular}

* Beginning vitamin D deficiency may be present during these periods.

$\dagger$ Intake raised by the addition of calcium lactate.

5 lactating women reported on in a previous paper (16), 4 were in relatively late lactation with milk yields ranging from 280 to 460 cc. per day, and it was possible for them to store calcium on intakes varying from 400 to $700 \mathrm{mgm}$. However, this was possible only after the exhibition of vitamin D.

Metabolism of breast-fed infants. In 1937 Leitch (11) assembled all available recent data on calcium metabolism of normal infants fed exclusively on breast milk. The maximum recorded retention for the entire series was shown for each monthly period from the first to the sixth month. This ranged from 65 to $142 \mathrm{mgm}$. per day or from 29 to 68 per cent of the intake. In each instance the amount of calcium retained fell very much short of the requirement of 170 to $310 \mathrm{mgm}$. calculated for skeletal growth to maintain the calcium content of the body at 10 grams per kgm. Should such a state prevail, a skeleton of more inferior grade of calcification than that at birth would be built up, leading to rickets and osteoporosis. Leitch finds it difficult to reconcile his calculation with the anomalous situation where feeding of breast milk, the natural food for the infant, would lead to deterioration of the skeleton.

A review of the data on the 4 infants included in the present work (rearranged in Table XI) suggests that such an anomalous position need not arise if milk intake is adequate and if vitamin $D$ is operative. When such was the case, each of the 4 infants showed an average daily retention approaching the ideal calculated by Leitch and exceeding the maximum retention recorded in the literature. The explanation for such excellent retention in our infants is probably two-fold. First, the quantities of breast milk consumed were sufficient to provide a total intake of calcium to meet the requirement. Second, by virtue of the conserving and absorption-promoting action of vitamin $\mathrm{D}$, the retention of calcium became exceedingly efficient, from 76 to 86 per cent of the intake being retained. It is true that 2 of the infants (Cases $2 \mathrm{~b}$ and $3 \mathrm{~b}$ ) had rickets in which vitamin $\mathrm{D}$ treatment should give rise to extraordinary retention to restore the depleted skeletal store. However, the other 2 infants, who had no rickets to start with, exhibited the same high degree of calcium retention, suggesting that breast feeding in adequate amounts, fortified by vitamin $\mathrm{D}$, would lead to normal skeletal growth of the infant.

$V$ itamin $D$ in human milk. The position of the vitamin $\mathrm{D}$ content of human milk is rather vague. Hess (8) has demonstrated that, whereas $25 \mathrm{cc}$. of ordinary human milk daily failed to cure rickets in rats, the same could be made effective by treating the mother with ultraviolet irradiation. Outhouse, Macy and Brekke (22) reported that pooled milk from wet nurses on an average American dietary in amounts of 25,30 , or $40 \mathrm{cc}$. daily contained no antirachitic factor as tested on rachitic rats, although 30 cc. of cow's milk fed daily induced marked healing. Bunker, Harris and Eustis (2) found that milk of human mothers fed previously on "vitamin D" milk of the cow was potent in the antirachitic factor for the rat.

When the antirachitic potency of breast milk 
from mothers receiving vitamin D supplements is tested on the infant, it is generally believed that some, though uncertain, degree of protection is transferable to the suckling children. Weech (24), in a survey of 47 infants breast fed by mothers given cod liver oil, found that the degree of intensity of the rachitic process, as judged by roentgenograms of wrists and the product of serum calcium and phosphorus, was inversely proportional to the amount of cod liver oil administered. Even in the group of 4 women receiving the largest amount of cod liver oil (50 to 60 ounces in six months), 2 of the infants had $x$-ray evidence of rickets. Barnes, Cope, Hunscher and Brekke (1) studied a woman whose diet was superior in quality and, in addition, was fortified with 2 quarts of cow's milk daily in which 300 units of a vitamin $\mathrm{D}$ concentrate was incorporated. It was found that the milk secreted was not sufficiently enriched by vitamin $D$ to heal rickets in 3 colored infants, or in experimental rachitic rats. Her own breast-fed baby, however, showed no signs of rickets throughout the investigation.

From the observations presented in this paper, there is no doubt that the administration of vita$\min \mathrm{D}$ to the mother in ordinary therapeutic doses $(12,000$ to 24,000 international units) is capable of sufficiently enriching her milk by vitamin $D$ to prevent (Cases $1 b$ and $4 b$ ) or cure (Cases $2 b$ and $3 b)$ rickets in the infant. When vitamin $D$ is withheld from the mother for a period of three months or so, as in Case 4a, her milk will be sufficiently impoverished to produce early evidence of vitamin D deficiency in the infant. This demonstrates, in a somewhat novel way, the dependence of the infant on the mother from the standpoint of vitamin D nutrition via breast milk.

Importance of vitamin $D$ supplement to the mother during lactation. It is usually recommended that infants be started with vitamin $D$ supplements in the early months of life, while nursing mothers receive relatively scant attention in this respect. This work should give credence to the view that it is just as important to supplement the mother as the child, if not more so. Vitamin D administration to the lactating mother is necessary to maintain her in balance in case her skeletal store is normal, and to enable her to store calcium if she has prior skeletal depletion as in osteomalacia. In adequate doses, the administra- tion of vitamin D to the mother would supply her milk with antirachitic properties sufficient for the care of the child.

The minimal dosage for the mother that would be efficacious both for the mother and for the infant is not determined. The daily dosage of 12,000 to 24,000 international units is probably more than the minimal effective dose. Nor is there evidence to indicate that such dosage need be kept up uninterruptedly throughout the nursing period. However, to render a relatively small dosage of vitamin $D$ effective, it is important that the level of calcium intake be raised over the ordinary requirement. The recommended amount of 1 to 2 grams of calcium per day will likely be sufficient for the purpose.

\section{SUM MARY}

1. Data on calcium, phosphorus and nitrogen metabolism were obtained on 4 women while they were supplying breast milk to 4 infants from whom similar data were secured at the same time, showing intimate relationship in the state of vitamin $\mathrm{D}$ nutrition between the mother and the infant during the nursing period.

2. In the first set of cases, the mother had healing osteomalacia with good retention of calcium and abundant store of vitamin $\mathrm{D}$ during gestation, and the infant was born normal. During lactation the mother maintained herself in mineral balance on relatively high intake, while the infant retained the major portion of the calcium and phosphorus intake in the milk.

3. The second pair of cases consisted of a mother with osteomalacia and tetany and her infant with rickets and tetany. Both showed poor retention of calcium and phosphorus, but after vitamin $\mathrm{D}$ administration to the mother, the metabolic defects of the mother as well as the infant were corrected. The mother, as a result of vitamin D therapy, was able to absorb sufficient minerals not only for the heightened requirements of lactation but also for the reparation of her depleted skeletal store. The infant, after receiving the "vitaminized" milk, showed markedly improved mineral retention.

4. The third experiment was on a presumably normal wet nurse supplying breast milk to a rachitic infant born of an osteomalacic mother. The wet nurse had to have her calcium intake 
raised to 1.5 to 2.0 grams before she was able to maintain balance. The vitamin $\mathrm{D}$ given subsequently probably contributed to this favorable state of affairs. The infant showed poor calcium and phosphorus retention while on a Klim formula and on breast milk prior to vitamin $\mathrm{D}$ administration to the wet nurse; but after such supplement, the infant was very much improved in mineral retention as well as in the rachitic bone changes.

5. The last series of observations was made on an osteomalacic mother and her infant. The mother had a limited period of vitamin D therapy during gestation with sufficient improvement in her metabolic disorder to give birth to a normal baby. During lactation while vitamin $\mathrm{D}$ was being withheld, she began to show negative mineral balance on relatively high intake; and subsequently, when vitamin D therapy was reinstituted, good retention of calcium and phosphorus. The infant exhibited excellent mineral retention throughout the period of study, but as the mother was being depleted of vitamin $\mathrm{D}$, the urinary calcium excretion diminished and disappeared, corresponding with an increase in the stool. This phenomenon was interpreted as an early sign of vitamin D deficiency, for subsequent supply of vitamin $\mathrm{D}$ to the mother induced a reversal in the partition of calcium elimination between the urine and stool in favor of the former.

\section{CASE ABSTRACTS}

Case 1a. Mother, Mrs. Y. W. L. (Hospital Number 28572), a Chinese woman of 42 was first seen in October 1933 for pain in the bones and debility of three years' duration. Her detailed history was reported in paper II (12) of this series. Briefly stated, she presented a case of advanced osteomalacia with marked skeletal decalcification, deformities and fractures dating back to July 1930 when she gave birth to her fourth child. Her serum calcium was 8.8 and inorganic phosphorus $2.2 \mathrm{mgm}$. per $100 \mathrm{cc}$., findings that justify the classification of her case as one of low-phosphorus osteomalacia.

She went through detailed metabolic studies from November 1933 to June 1934. Her dramatic response to vitamin $\mathrm{D}$ therapy from the symptomatic, roentgenologic and metabolic standpoints was given in paper II (12) and her behavior toward varying levels and ratios of calcium to phosphorus intake was presented in paper III (13).

In September 1934 the patient was readmitted with a slight recurrence of the pain in the bones and difficulty in walking. Her appetite was poor, with occasional nausea and vomiting. She was found to be pregnant with the expected date of confinement on April 15, 1935. Although slight tenderness was present over the lumbar spine and ribs, roentgenologic examination of the skeleton showed no evidence of exacerbation in osteomalacia. Serum calcium was 8.92 and inorganic phosphorus 2.82 . There was minimal pulmonary tuberculosis at right upper lung. A slight degree of anemia developed shortly after admission. Hemoglobin remained at 10 grams, and erythrocyte count at 3.2 millions, in spite of the administration for prolonged periods of ferric ammonium citrate and hydrochloric acid by mouth, and liver extract intramuscularly. Her calcium, phosphorus and nitrogen metabolism was studied throughout pregnancy. From December 1934 to April 1935 her calcium intake was approximately 2 grams per day, and vitamin $D$ in the form of Vigantol was given in doses of from 1 to $3 \mathrm{cc}$. a day ( $1 \mathrm{cc}$. is equivalent to 12,000 international units of vitamin D). During this period of four months, 40 to 50 per cent of the intake of calcium was retained. This would enable her not only to meet the fetal requirements, but also to replenish her own skeletal store of calcium.

The course of gestation was fairly smooth except for an attack of abdominal pain in the latter part of the pregnancy. In view of the pelvic deformities, a cesarean section was performed by Dr. J. P. Maxwell on April 13,1935 , and a normal male baby (weighing 2,885 grams) was delivered. The postoperative course was satisfactory. The patient was studied again from the viewpoint of lactation. The studies began eighteen days postpartum, and were continued for 11 four-day periods. This part of the studies, together with observations on other patients during lactation, was reported in Paper VI (14).

The patient was discharged on June 15, 1935 in good condition. She remained well and nursed her baby until September 1936 when she began to have diarrhea, abdominal distension and swelling of legs. On reentry into the hospital in November, although her diarrhea subsided, her general condition deteriorated considerably. There was anasarca with ascites and enlarged liver. Plasma proteins were 1.31 per cent albumin and 2.72 per cent globulin. The pulmonary tuberculosis at right upper lung showed extension. In the right breast there was a firm mass measuring $10 \times 8 \times 5 \mathrm{~cm}$. associated with enlarged axillary lymph nodes. There had been a firm nodule in her breast for eight years, showing no tendency to grow until four months prior to admission when rapid enlargement commenced. Biopsy of the tumor and axillary lymph gland revealed carcinoma in both, and the section of the sediment of the ascitic fluid withdrawn also exhibited malignant tumor cells. As radical operation was not considered advisable in view of the advanced stage of the disease and of the patient's poor general condition, a course of intensive deep radiotherapy was given to the breast and axilla. Although the tumor masses diminished in size, the general condition of the patient went downhill. Death took place at home in February 1937.

Case 1b. Infant, Y.W. L. (Hospital Number 49062), 
was the fifth child of the mother described above. Although the mother had osteomalacia, this was largely healed, and she received large amounts of calcium and vitamin $\mathrm{D}$ during gestation. The child delivered at term on April 13, 1935 by cesarean section weighed 2,885 grams and measured $53 \mathrm{~cm}$. in length. He was normal in every respect. There was no clinical evidence of rickets. Cord blood serum calcium was $11.1 \mathrm{mgm}$. per cent. Roentgenologic examination of the bones of the upper and lower extremities showed normal size, contour and density. He was fed exclusively on mother's milk. Metabolic studies commenced on the twenty-sixth day after birth and proceeded smoothly for 7 four-day periods. General condition remained excellent and weight gain was uninterrupted. On discharge on June 12 , he weighed 5,600 grams, almost doubling birth weight.

Case 2a. Mother, Mrs. C. S. Y. (Hospital Number 58397), age 31, was admitted on April 4, 1937 for general bodily ache, tingling and spasm of extremities for a year and a half. In December 1934 she gave birth to her first baby, which was breast fed until June 1936, when it died. In November 1935, while lactating, she began to have bony aches, followed by numbness and spasticity of the limbs. Active tetanic attacks occurred usually after exposure to cold or prolonged pressure on the limbs. The condition cleared up in April 1936 when she became pregnant for the second time. The bony aches and numbness began to recur in October and became progressively more debilitating. The second child was delivered spontaneously in February 1937. Spastic attacks returned after parturition.

After the birth of the second child, bowels were constipated and bleeding from rectum was frequently noticed on defecation. There was an attack of dysentery in September 1936. Diet consisted of corn, millet, wheat flour, rice and vegetables in season. Meat and eggs were very rarely eaten.

On admission the patient appeared well developed, fairly well nourished and not in acute distress. Temperature $37.4^{\circ} \mathrm{C}$., pulse 88 , blood pressure $110 / 70$, weight $48 \mathrm{kgm}$. Breasts were lactating with marked venous engorgement. Spleen was just palpable. Hemorrhoids, both external and internal, were present and bled on digital examination. There were no skeletal deformities, although pain was complained of in the shoulders, lumbar spine and thighs on motion. The patella tendon reflexes were hyperactive; and both Chvostek's and Trousseau's signs were positive. Urine was normal except for the presence of sugar which proved to be lactose. Blood picture was not remarkable. Serum calcium was 7.46 and inorganic phosphorus $4.70 \mathrm{mgm}$. per $100 \mathrm{cc}$; phosphatase was 12.9 Bodansky units. On x-ray examination slight osteoporosis was present in all the visualized bones, but no deformities.

Metabolic studies were started on April 6. The patient developed dysentery with 7 to 10 blood and mucuscontaining stools a day. Low-grade fever was present. Tetany at times became manifest, requiring calcium gluconate intramuscularly for relief. B. dysenteriae, mannite-fermenting group, was isolated from the stools.
Fortunately, the attack subsided in six days and was not sufficiently serious to interrupt the metabolic regime. After 3 control periods Vigantol $1 \mathrm{cc}$. daily was given, and marked symptomatic improvement in the bony aches, numbness and spasticity was noticed.

After 6 periods of metabolic studies, there was a recurrence of dysentery necessitating suspension of the rigid quantitative regime. While the administration of Vigantol and high calcium intake were maintained, a semi-liquid diet and doses of sodium sulphate were given. In twelve days the bowel condition returned to normal. Metabolic studies were then resumed for 3 periods before the patient was discharged in good condition on May 25, 1937.

Case 2b. Infant, C. C. C. (Hospital Number 58396), a male baby, aged 57 days, was admitted on April 4, 1937 for convulsive attacks for four days prior to entry. Although the mother had tetany and osteomalacia as stated above, the birth of the baby was spontaneous and easy. Feeding was exclusively on breasts. The onset of convulsive seizures was sudden without any previous illness. They were generalized with retraction of head, deviation of mouth, upward rolling of eyeballs and spastic and clonic contractions of all extremities. Each attack lasted from five to ten minutes.

Examination showed good development and nutrition. Although no convulsions were noticed, both hands and feet were held in spasm, and Trousseau's and Chvostek's signs were present. The anterior fontanelle was wide open, but craniotabes, rosary and enlargement of the wrists were absent. Liver and spleen were palpable and hydrocele of tunica vaginalis was noted on both sides.

Urine and blood count were normal and stools contained some mucus. Blood serum calcium was 7.8 and phosphorus $8.0 \mathrm{mgm}$. per cent; phosphatase was 19.6 units (Bodansky). Plasma proteins were 3.11 per cent albumin and 1.62 per cent globulin. X-ray films showed a slight condensation, haziness and lipping at the distal ends of radii, ulnae, tibiae and fibulae. The bones were slightly osteoporotic. These changes were suggestive of mild rickets, but over the lateral aspects of both femurs there was considerable periosteal thickening.

After admission the spastic phenomenon was promptly controlled by doses of calcium gluconate intramuscularly and calcium chloride orally. Metabolic experiments were started at the same time as those on the mother whose milk constituted the sole form of feeding. The studies went on well for 1 period, but during the second and third periods they had to be discontinued on account of a severe local vaccinia reaction to smallpox vaccination, accompanied by fever and return of convulsive attacks. The latter were again controlled by parenteral calcium gluconate and oral calcium chloride, and the whole episode subsided in three or four days. The baby was put on the metabolic regimen again from the fourth period on, and satisfactory studies were carried on for 9 more periods.

The infant was discharged in good condition on May 25, 1937. Serum calcium and phosphorus were 11.32 and $5.61 \mathrm{mgm}$. per cent, respectively. X-ray examination, 
repeated on the day of discharge, showed no obvious changes in the bones from that on admission. The weight gain was from 4,900 to 6,100 grams in the course of seven weeks.

Case 3a. Mother, Mrs. T. W. T. (Hospital Number 61219 ), a Chinese woman of 38 , was admitted on November 29, 1937 with the chief complaint of pain in the lumbar region for thirteen months and in both thighs for five months. She began to have pain in the lower back soon after the onset of her eighth pregnancy thirteen months prior to admission. The pain gradually increased in severity, resulting in difficulty in walking throughout the first and second trimesters of pregnancy. In the latter part of pregnancy the pain also involved the thighs. She was completely bedridden shortly before parturition and has remained so since. Her parturition which took place in August 1937 was slow but spontaneous. The baby (Case $3 \mathrm{~b}$ ) was found to have rickets at the same time that the mother was seen. He was breast fed by the mother but the milk secretion was extremely poor. The patient had attacks of numbness and spasm of hands throughout the course of present illness. She was married at 17, and gave birth to eight children, the eldest one being 20 years of age. She had tingling sensation, spasm of hands and pain in the lower back during her sixth and seventh pregnancies six and four years prior to admission, respectively. Her husband, being a peddler, could scarcely earn enough to feed a family of seven. The diet was extremely inadequate and the patient led a secluded life.

Examination revealed that she was completely disabled in bed, complaining of pain in the muscles and bones whenever she was moved. She had marked muscle spasm and tenderness in the thighs and over the lower ribs. Slight scoliosis and kyphosis of lumbar spine, slight rostration of the symphysis pubis and very narrow pubic arch were present. Signs of Chvostek and Trousseau were positive. Head organs were normal. Thyroid was slightly enlarged. There were no important abnormal findings in the chest and abdomen. Routine laboratory studies, including blood Wassermann test, blood counts, urinalysis and stool examinations were all negative except for a slight transient lactosuria. Fasting blood sugar and non-protein nitrogen were within normal range. Serum calcium was 6.87 and inorganic phosphorus 2.75 mgm. per cent. Plasma proteins were 2.51 per cent albumin and 5.66 per cent globulin. Basal metabolic rate was +21.2 per cent. $\mathrm{X}$-ray examination revealed marked osteoporosis of all the bones, exceedingly marked biconcave deformity of the vertebral bodies, eversion and old fractures of the pubic bones. The right upper lung field appeared slightly clouded.

Metabolic observation extended from December 6, 1937 to April 15, 1938. Her response, clinically and metabolically, to ultraviolet irradiation was reported in paper VII (4) of this series. She gained $9 \mathrm{kgm}$. of weight in four and one-half months, and was discharged on April 16, 1938 much improved symptomatically and roentgenologically.

Case 3a'. Wet nurse, Mrs. W. C. S. (Hospital number
61624 ), age 23 , was admitted on January 14,1938 as a wet nurse for baby T. N. T. (Case $3 b$ described below). Her past history was irrelevant. She was married a year prior to admission and became pregnant soon afterwards. The course of pregnancy was smooth, and a male child weighing $5 \mathrm{lbs}$. was delivered spontaneously at term on December 17, 1937. The child was fed on her breast soon after birth. The diet for the past year consisted of rice, wheat flour, millet, corn meal and salted and fresh vegetables, but practically no meat or eggs.

Physical examination showed good development and nutrition. Weight $52.2 \mathrm{kgm}$., height $161 \mathrm{~cm}$. There were no skeletal deformities, bone tenderness, nor signs of tetany. Both breasts were lactating. Except for moderate gingivitis, pharyngitis and endocervicitis, the rest of the physical findings were normal.

Routine urine, blood and stool examinations were normal. Blood Wassermann reaction was negative. Serum calcium and phosphorus were 9.07 and $4.78 \mathrm{mgm}$. per cent, respectively (January 15). Calcium, phosphorus and nitrogen balance studies were started on January 19 and carried out for a total of 22 four-day periods. These included observations on the effects of various levels of calcium and phosphorus intake and of vitamin D therapy. The patient was discharged on April 14 in good condition.

Case 3b. Infant, T. N.T. (Hospital Number 61227), male, age three months, was admitted on November 30 , 1937 for investigation for possible rickets or tetany on account of advanced osteomalacia in the mother. As mentioned before (Case 3a), this was the eighth child, and his birth was at term and spontaneous but prolonged. As the mother's milk secretion was scanty, breast feeding had to be supplemented by hsin erh cha (almond tea), oufen (lotus root starch) and kao kan (rice flour cake). When two months old the infant had an attack of high fever followed by convulsions lasting for half a day.

Physical development and general nutrition were fair; weight was 5,260 grams. The anterior fontanelle was wide open and the posterior fontanelle partially so. Parietal bosses, Harrison's groove, enlargement of the costochondral junctions and widening of the wrists were noticeable. The head organs were normal except for some nasal discharge and the lungs and heart showed no abnormality. The abdomen was prominent with both spleen and liver palpable at $1 \mathrm{~cm}$. below costal margin.

Urinalysis and stool examinations were normal. Blood showed 10.5 grams hemoglobin, 3.4 million red blood cells, and 11,250 white blood cells with 35 per cent polymorphonuclear leukocytes and 62 per cent lymphocytes. Serum calcium was 5.18 and inorganic phosphorus 5.94 mgm. per $100 \mathrm{cc}$. and phosphatase was 13.7 Bodansky units. Roentgenograms exhibited moderate osteoporosis of all the bones with slight haziness and cupping of the distal epiphysial ends of all the long bones of the forearms and legs. Slight beading was observed at the anterior aspects of all the ribs. The diagnosis was moderate rickets (Figure 5). This was likely to be of fetal origin.

For 3 four-day periods (designated as A, B, C; De- 
cember 22, 1937 to January 2, 1938, inclusive) while on a formula of "Klim" with a small amount of breast milk from the mother, the calcium, phosphorus and nitrogen balances were observed.

On January 18 and 19, attacks of generalized convulsions occurred. Serum calcium and phosphorus were respectively 4.77 and $6.40 \mathrm{mgm}$. per cent. Calcium ion was $2 \mathrm{mgm}$. per cent, as determined by the frog heart method (20) and $2.4 \mathrm{mgm}$. per cent by calculation from total calcium and serum proteins (5.56 grams per cent) according to McLean and Hastings (21). It was considered that the convulsive attacks were a manifestation of tetany. Calcium gluconate (Sandoz) 10 per cent 10 cc. (90 mgm. calcium) was given intramuscularly daily from January 19 to 26 (periods 1 and 2), while the feeding consisted of breast milk from the wet nurse and " Klim," $420 \mathrm{cc}$. each daily, with additions of orange juice.

From January 27 on, calcium gluconate 3 per cent solution was given by mouth in daily doses of $27 \mathrm{cc}$. (73 mgm. calcium) instead of the 10 per cent solution intramuscularly and the wet nurse received Vigantol $1 \mathrm{cc}$. $(12,000$ international units vitamin D) daily. The amount and proportion of "Klim" and breast milk remained approximately the same. While on this regime, balance studies were made on the child for 2 periods from February 4 to 11 (periods 5 and 6 ).

On February 11 rhinitis developed with purulent discharge from which virulent $B$. diphtheriae were isolated. There was a low-grade fever. Leukocyte count was 10,450 with 52 per cent polymorphonuclears. A total dose of 20,000 units of a concentrated form of diphtheria antitoxin was given intramuscularly in divided doses on February 12 and 13 . There was some febrile reaction following the serum treatment. Though the nasal discharge cleared up promptly, positive K. L. B. cultures were obtained on several subsequent occasions.

While on essentially the same regime, except for the omission of calcium gluconate by mouth, 2 more periods (periods 9 and 10) of metabolic observations were secured from February 20 to 27 . From March 8 to 15 (periods 13 and 14) and from March 20 to 27 (periods 16 and 17), feeding was entirely on the breast milk from the wet nurse and the calcium and phosphorus intake was maintained by the addition of a 7.7 per cent solution of calcium lactate $48 \mathrm{cc}$. daily ( $480 \mathrm{mgm}$. calcium), and a solution of disodium phosphate (422 mgm. phosphorus).

The last 2 periods (periods 19 and 20) of metabolic studies were from April 1 to 8 when the feeding was entirely on "Klim," the calcium lactate being omitted.

Just prior to discharge on April 18, 1938, x-ray examination showed evidence of healing of rickets with increased bony density in the course of four months (Figure 6). Body weight on discharge was 6,700 grams.

Case 4a. Mother, Mrs. W. H. S. (Hospital Number 65376), age 29, was admitted on December 9, 1938 for bony aching, particularly of the pelvis and lumbar region, with occasional carpopedal spasm for eleven years prior to entry. She was married in 1926, led an indoor life in a cave dwelling in Pingyao, Shansi, and subsisted mainly on cereals and vegetables. Her symptoms, which began shortly before her first pregnancy in 1927, were considerably aggravated during gestation so that she was confined to bed on account of bone pains and spastic attacks. However, the delivery was spontaneous without difficulty, and lactation was abundant. In the course of two years the symptoms were gradually improved. On getting up she noticed that her stature dwindled by several inches with knock-knee and pelvic deformities. In 1933, she became pregnant for the second time, and the gestation was terminated by medication at the third month. Her symptoms were aggravated especially during the winter. She was examined in this hospital for the first time in April 1936, when a course of calcium lactate, cod liver oil and ultra violet radiation gave rise to considerable improvement. She returned to Shansi and was pregnant for the third time in March 1937. The backache and leg pains recurred and the pregnancy was artificially aborted at the fourth month. Her fourth pregnancy started in May 1938 and she was admitted during the eighth month of gestation.

Examination showed undernutrition and stunted stature. Weight $44.2 \mathrm{kgm}$. and height $154 \mathrm{~cm}$. The lower extremities were particularly short in comparison with the trunk and upper extremities. The gait was unsteady with the pelvis tilted from one side to the other in walking, while only very short steps could be made. The thighs were strongly adducted and internally rotated, and the knees knocked against each other. The right lower extremity was shorter than the left by $4 \mathrm{~cm}$. Definite tenderness was present over the ribs, spine, pelvis and femurs. Chvostek's sign was negative, but Trousseau's sign was positive. The heart and lungs were normal. The blood pressure was 80/50. The abdomen was enlarged by the gravid uterus, the fundus of which came up to $28 \mathrm{~cm}$. above the symphysis pubis. Fetal movements and heart sounds were heard. The pelvis was contracted and the transverse outlet measured $7 \mathrm{~cm}$.

Routine urine and stool examinations were normal. Blood count showed 11.2 grams hemoglobin, 3.3 million red blood cells, and 6,500 white blood cells, with 77 per cent polymorphonuclears. Serum calcium was 8.24 and phosphorus $2.77 \mathrm{mgm}$. per cent, and phosphatase $2.3 \mathrm{Bo}$ dansky units. Plasma non-protein nitrogen was $21 \mathrm{mgm}$. per cent, and proteins were 2.97 per cent albumin and 3.24 per cent globulin. Basal metabolic rate was plus 6.7 per cent. Blood Wassermann reaction was negative. Roentgenologic survey of the skeleton showed moderate degree of osteoporosis in all the long bones, slight biconcave absorption of the vertebral bodies with irregular curvature of the sacrum, asymmetry of the pelvis, distortion and compression of the head of the femur into the acetabulum and pathological fracture of the right upper femur.

Metabolic studies commenced on December 26 and proceeded for 10 four-day periods prior to the termination of pregnancy. The first 4 periods served as control on high calcium intake alone, and the fifth period was used for the administration of Vigantol in daily doses of $\mathbf{5}$ cc. $(60,000$ international units of vitamin D). During the next 5 periods, definite progressive increase in cal- 
cium and phosphorus retention was noticed, with subjective improvement. Serum calcium and phosphorus were 9.46 and $3.86 \mathrm{mgm}$. per cent, respectively.

Cesarean section was performed by Drs. H. L. Hsu and S. Lin on February 7, 1939, and a normal male child weighing 2,920 grams was delivered. The puerperium was satisfactory and lactation active. She received 30 cc. cod liver oil daily for six days immediately after parturition.

Metabolic observation on lactation and its effect on the infant was started on February 24, and continued for 26 four-day periods (one hundred and four days). The results are presented in the text. The patient was discharged in excellent condition on June 11, 1939.

Case 4b. Infant, W. H. S. (Hospital Number 66085), was a male baby born on February 7, 1939 by cesarean section of an osteomalacic mother who received a limited dose of Vigantol and liberal amounts of calcium during the latter part of pregnancy, as described above. The child weighed 2,920 grams and measured $49.5 \mathrm{~cm}$. in length at birth. He was in every way normal. There were no bony deformities and $\mathbf{x}$-ray of the bones showed normal texture with sharp outline and smooth diaphyseal ends (Figure 7). Urine was normal. Blood count showed 9.8 grams hemoglobin, 4.14 million red blood cells, 7,600 white blood cells, with 53 per cent polymorphonuclears. Serum calcium was 10.8 and phosphorus $6.03 \mathrm{mgm}$. per $100 \mathrm{cc}$. and phosphatase 8.2 Bodansky units.

Mother's milk constituted the only form of feeding. Metabolic observations were started on February 24, and continued for 2 four-day periods followed by 2 four-day periods without metabolic studies. Thereafter, 2 "observation" periods alternated with 2 "rest" periods. From May 7, that is, after the elapse of 18 periods, the mother received Vigantol $2 \mathrm{cc}$. $(24,000$ international units of vitamin D) per day for 8 periods, during which metabolic observations were continued on the infant to ascertain the effect of "vitaminized" milk. Throughout the course of study, the infant took the prescribed feedings quantitatively, remained in excellent condition and gained weight steadily. On discharge on June 11 , he weighed 7,000 grams, almost two and one half times the birth weight in the course of four months, although slight anemia persisted.

\section{BIBLIOGRAPHY}

1. Barnes, D. J., Cope, F., Hunscher, H. A., and Brekke, V., Human milk studies. XVI. Vitamin D potency as influenced by supplementing the diet of the mother during pregnancy and lactation with cow's milk fortified with a concentrate of cod liver oil (test on rachitic infants and rats). J. Nutrition, 1934, 8, 647.

2. Bunker, J. W. M., Harris, R. S., and Eustis, R. S., The antirachitic potency of the milk of human mothers fed previously on vitamin D milk of the cow. New England J. Med., 1933, 208, 313.

3. Chu, F. T., and Sung, C., Tetany in infancy and childhood: a clinical study of 45 cases seen in North China with especial reference to etiology. J. Pediat. (To be published).

4. Chu, H. I., Yu, T. F., Chang, K. P., and Liu, W. T., Calcium and phosphorus metabolism in osteomalacia. VII. The effect of ultra violet irradiation from mercury vapor quartz lamp and sunlight. Chinese Med. J., 1939, 55, 93.

5. Donelson, E., Nims, B., Hunscher, H. A., and Macy, I. G., Metabolism of woman during the reproductive period. IV. Calcium and phosphorus utilization in late lactation and during subsequent reproductive rest. J. Biol. Chem., 1931, 91, 675.

6. Garry, R. C., and Stiven, D, A brief review of recent work on dietary requirements in pregnancy and lactation, with an attempt to assess human requirements. Nutrition Abstr. and Rev., 1936, 5, 855.

7. Hannon, R. R., Liu, S. H., Chu, H. I., Wang, S. H., Chen, K. C., and Chou, S. K., Calcium and phosphorus metabolism in osteomalacia. I. The effect of vitamin $D$ and its apparent duration. Chinese Med. J., 1934, 48, 623.

8. Hess, A. F., Weinstock, M., and Sherman, E., The production of antirachitic properties in human milk resulting from irradiation of the mother. Proc. Soc. Exp. Biol. and Med., 1925-26, 23, 636.

9. Hummel, F. C., Sternburger, H. R., Hunscher, H. A., and Macy, I. G., Metabolism of women during the reproductive cycle. VII. Utilization of inorganic elements; continuous case study of multipara. J. Nutrition, 1936, 11, 235.

10. Hunscher, H. A., Metabolism of women during the reproductive cycle. II. Calcium and phosphorus utilization in two successive lactation periods. J. Biol. Chem., 1930, 86, 37.

11. Leitch, I., The determination of the calcium requirements of man. Nutrition Abstr. and Rev., 1937, 6, 553.

12. Liu, S. H., Hannon, R. R., Chu, H. I., Chen, K. C., Chou, S. K., and Wang, S. H., Calcium and phosphorus metabolism in osteomalacia. II. Further studies in the response to vitamin D of patients with osteomalacia. Chinese Med. J., 1935, 49, 1.

13. Liu, S. H., Hannon, R. R., Chou, S. K., Chen, K. C., Chu, H. I., and Wang, S. H., Calcium and phosphorus metabolism in osteomalacia. III. The effects of varying levels and ratios of intake of calcium to phosphorus on their serum levels, paths of excretion and balances. Chinese J. Physiol., 1935, 9, 101.

14. Liu, S. H., Su, C. C., Wang, C. W., and Chang, K. P., Calcium and phosphorus metabolism in osteomalacia. VI. The added drain of lactation and beneficial action of vitamin D. Chinese J. Physiol., 1937, 11, 271.

15. Macy, I. G., Hunscher, H. A., McCosh, S. S., and Nims, B., Metabolism of women during the reproductive cycle. III. Calcium, phosphorus, and nitrogen utilization in lactation before and after supple- 
menting the usual home diets with cod liver oil and yeast. J. Biol. Chem., 1930, 86, 59.

16. Maxwell, J. P., and Turnbull, H. M., Two cases of fetal rickets with report on histology of bones. J. Path. and Bact., 1930, 33, 327.

17. Maxwell, J. P., Hu, C. H., and Turnbull, H. M., Fetal rickets. J. Path. and Bact., 1932, 35, 419.

18. Maxwell, J. P., Further studies in adult rickets (osteomalacia) and fetal rickets. Proc. Roy. Soc. Med., 1935, 28, 265.

19. Maxwell, J. P., Pi, H. T., Lin, H. A. C., and Kuo, C. C., Further studies in adult rickets (osteomalacia) and fetal rickets. Proc. Roy. Soc. Med., 1939, 32, 287.

20. McLean, F. C., and Hasting, A. B., Biological method for estimation of calcium iron concentration. J. Biol. Chem., 1934, 107, 337.
21. McLean, F. C., and Hastings, A. B., Clinical estimation and significance of calcium ion concentration in blood. Am. J. Med. Sc., 1935, 189, 601.

22. Outhouse, J., Macy, I. G., and Brekke, V., Human milk studies. V. A quantitative comparison of the antirachitic factor in human milk and cow's milk. J. Biol. Chem., 1928, 78, 129.

23. Tso, E., and Chu, F. T., Nitrogen metabolism in infants on graded intake of soybean milk proteins. Chinese J. Physiol., 1931, 5, 287.

24. Weech, A. A., The influence of the administration of cod liver oil to the mother on the development of rickets in the infant. Bull. Johns Hopkins Hosp., 1927, 40, 244.

25. Wu, H., and Yen, D. Y., The nutritive value of Chinese foods. Chinese J. Physiol., 1928, Rep. Ser. $1,135$. 